University of Louisville

ThinkIR: The University of Louisville's Institutional Repository

$12-2010$

\title{
Investigation whether the German credit financial market is promising for consulting fees as an alternative to traditional commission banking.
}

Alexandra Antonia Behrens 1979-

University of Louisville

Follow this and additional works at: https://ir.library.louisville.edu/etd

\section{Recommended Citation}

Behrens, Alexandra Antonia 1979-, "Investigation whether the German credit financial market is promising for consulting fees as an alternative to traditional commission banking." (2010). Electronic Theses and Dissertations. Paper 95.

https://doi.org/10.18297/etd/95

This Master's Thesis is brought to you for free and open access by ThinkIR: The University of Louisville's Institutional Repository. It has been accepted for inclusion in Electronic Theses and Dissertations by an authorized administrator of ThinkIR: The University of Louisville's Institutional Repository. This title appears here courtesy of the author, who has retained all other copyrights. For more information, please contact thinkir@louisville.edu. 


\title{
INVESTIGATION WHETHER THE GERMAN CREDIT FINANCIAL MARKET IS PROMISING FOR CONSULTING FEES AS AN ALTERNATIVE TO TRADITIONAL COMMISSION BANKING
}

\author{
By
}

Alexandra Antonia Behrens

Diplom-Wirtschaftsingenieurin (FH), Hamburger Fern-Hochschule, 2007

\author{
A Thesis \\ Submitted to the Faculty of the \\ Graduate School of the University of Louisville \\ in Partial Fulfillment of the Requirements \\ for the Degree of
}

MASTER OF SCIENCE

Department of Industrial Engineering

University of Louisville

Louisville, Kentucky

December 2010 


\section{Copyright 2010 by Alexandra Behrens}

All rights reserved 

INVESTIGATION WHETHER THE GERMAN CREDIT FINANCIAL MARKET IS PROMISING FOR CONSULTING FEES AS AN ALTERNATIVE TO TRADITIONAL COMMISSION BANKING

Submitted by Alexandra A. Behrens

\begin{abstract}
A Thesis Approved on
July $8^{\text {th }}, 2010$

By the Following Reading and Examination Committee:

Dr. Gerald Evans, Thesis Director

Dr. William Biles

Dr. Tim Hardin
\end{abstract}




\section{ACKNOWLEDGEMENT}

At this point, I'd like to thank everybody who supported me during the last year with my studies at the University of Louisville and in particular in developing this thesis.

Sincere thanks go to my thesis director Dr. Gerald Evans who, although thousands of miles away, supported me during my studies in Germany (e.g., the Simulation course) and in establishing this thesis.

In addition, I'd like to thank Dr. William Biles and Dr. Tim Hardin for their final suggestions.

Special thanks go to my former university coordinator Susanne Kaupp-Beller in Stuttgart, Germany, for her support with distributing questionnaires for the conducted survey this thesis is based on. Moreover, I'd like to thank everybody who participated in my survey and thus helped me find results in order to draw reasonable conclusions.

Special thanks, too, go to my parents Christine and Berthold and to all my good friends and study colleagues who constantly encouraged me to go on.

Last but not least, I want to thank my husband Ralf for his professional and editorial support in establishing this thesis. Without him and his love, I could not have succeeded so far. 


\title{
ABSTRACT \\ INVESTIGATION WHETHER THE GERMAN CREDIT FINANCIAL MARKET IS PROMISING FOR CONSULTING FEES AS AN ALTERNATIVE TO TRADI- TIONAL COMMISSION BANKING
}

\author{
Alexandra A. Behrens
}

July $8^{\text {th }}, 2010$

This thesis is written to investigate if and how far the German credit financial market could be promising for consulting fees in the field of mortgage loan banking.

The problem identified is an extensively discussed issue in the German credit financial sector. In solving the problem the author made some literature research and points out different modes of determining consulting fees. The author faces the challenge that, up to now, there is hardly any literature on the application of mortgage loan consulting fees in Germany. Secondly, a form concerning mortgage loan related business in conjunction with customers' attitudes towards consulting fees was designed and distributed for a survey. In addition to the survey, a Monte Carlo simulation model shows the coherence of debiting consulting fees and the possibility of economies of scale for German retail banks.

The results of the study as well as the simulation model are astonishing and pathbreaking for further research on this topic in that there seems to be a basic willingness among prospects to pay consulting fees for mortgage loan consulting services that are presently offered for "free" in Germany. Another main finding constitutes that even rather small consulting fees have a great effect on the revenue of the bank. 


\section{TABLE OF CONTENTS}

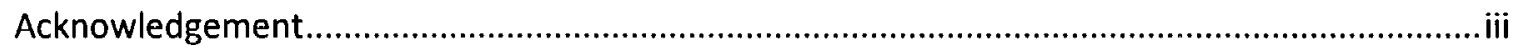

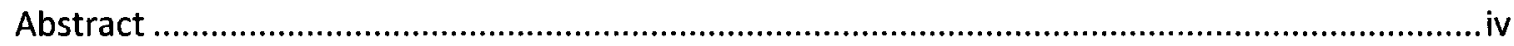

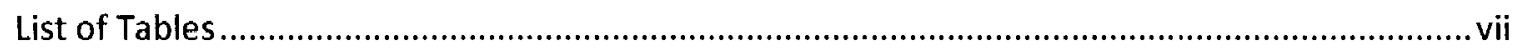

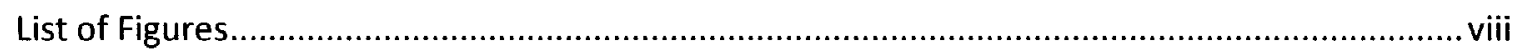

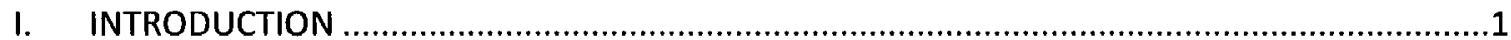

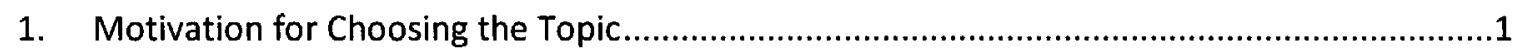

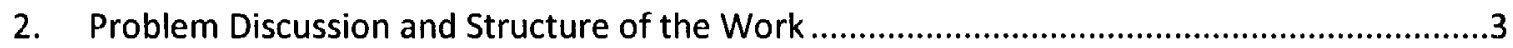

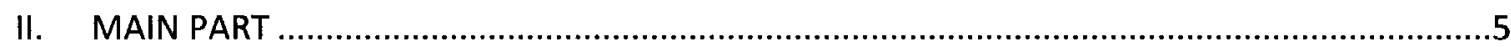

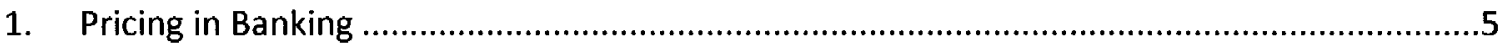

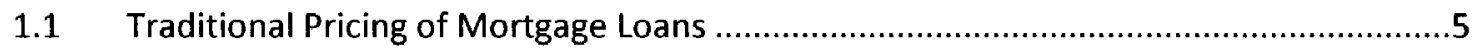

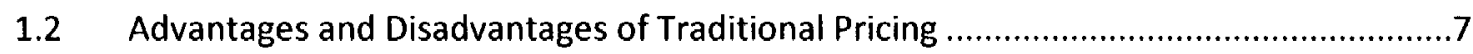

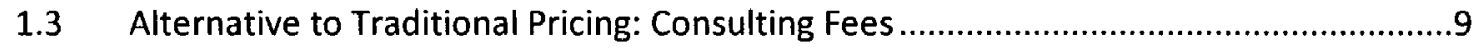

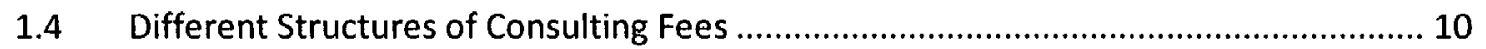

1.5 True Value of a Mortgage Loan Consulting Service ............................................. 17

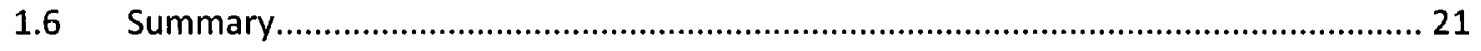

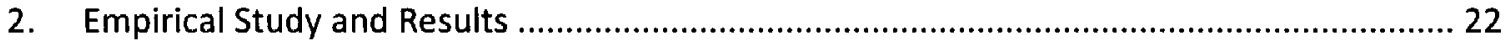

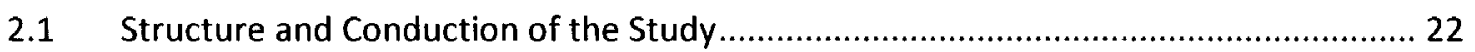

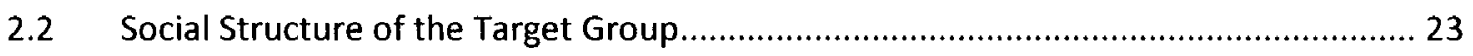

2.3 Questions and Results related to Mortgage Loan Banking and Consulting Fees in Detail

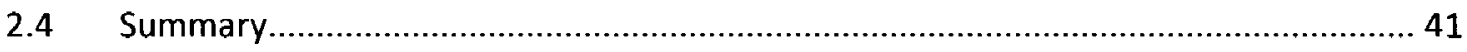

3. Monte Carlo Simulation: Effects of Consulting Fees on the Revenue of Mortgage Loan

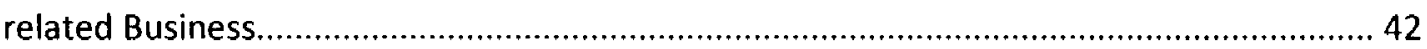

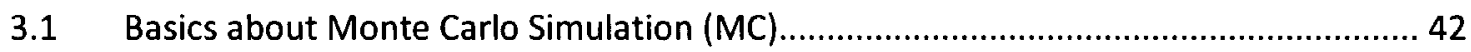

3.2 Structure of the Mortgage Loan Revenue Model ...................................................... 42

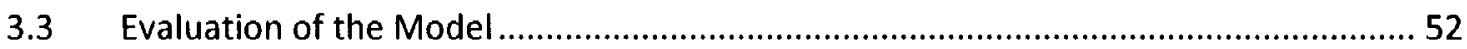

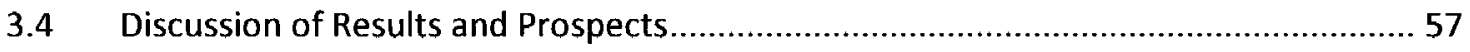

3.5 Possible Approaches to introduce a Mortgage Loan Consulting Fee in German Retail banks. 


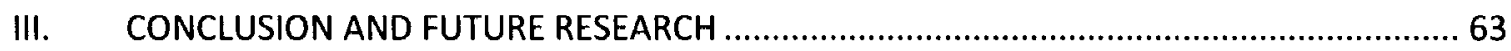

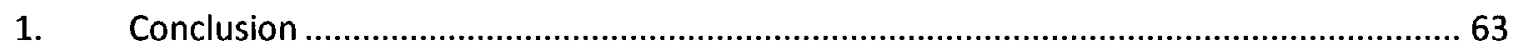

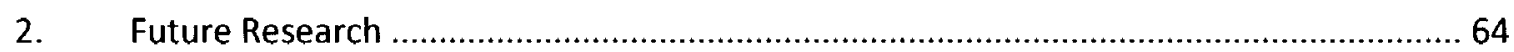

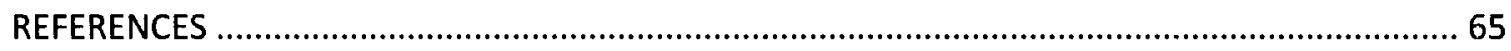

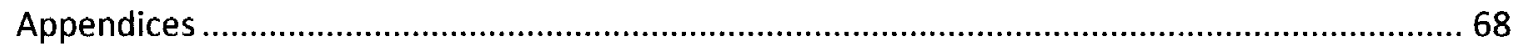

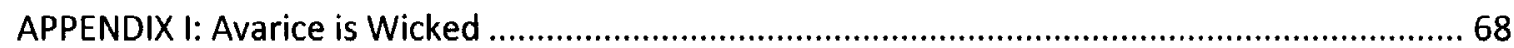

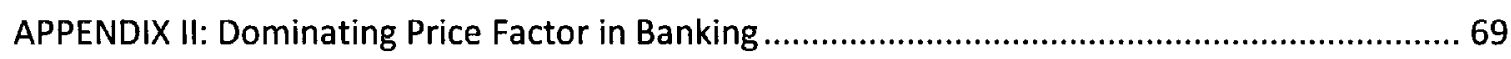

APPENDIX III: Credit Rating related Mortgage Loan Prices ........................................................ 70

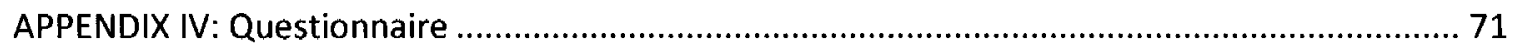

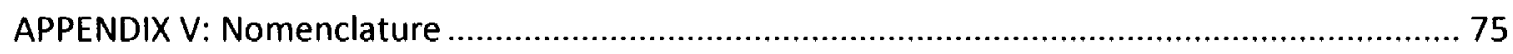

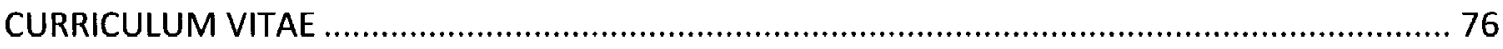




\section{LIST OF TABLES}

TABLE I VOLUME-RELATED DIFFERENTIATION

TABLE II PROCESS STEPS AND DURATION OF AN EXTENSIVE MORTGAGE LOAN

CONSULTANCY (WORST CASE APPROACH).

TABLE III ADDITIONAL PROCESS STEPS FOR NEW CUSTOMERS

TABLE IV DETERMINING THE LABOR COSTS PER HOUR OF A BANK ADVISOR

TABLE V FIXED COSTS VERSUS VARIABLE COSTS

TABLE VI CONSULTING FEE DEPENDING ON THE AMOUNT BORROWED 34

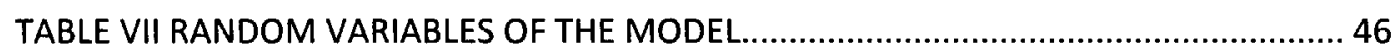

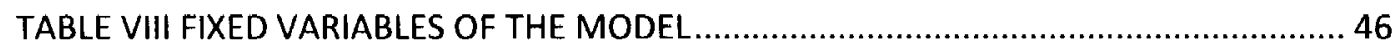

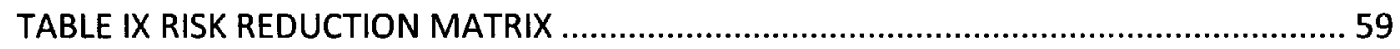

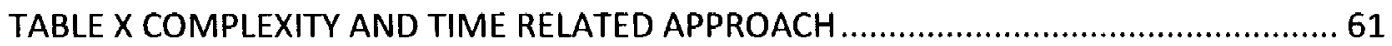




\section{LIST OF FIGURES}

FIGURE 1: Age Pattern; Results of Question Number 10....................................... 23

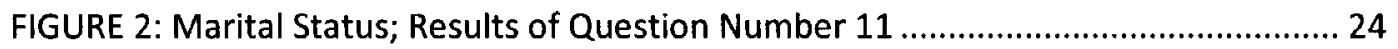

FIGURE 3: Occupation Group; Results of Question Number 12 .................................. 25

FIGURE 4: Which Category of Financial Institution does the Bank belong to where you concluded your Mortgage Loan Agreement / which Category of Financial Institution do you

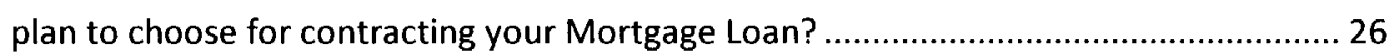

FIGURE 5: Why exactly did you choose / do you plan to choose that Bank for contracting

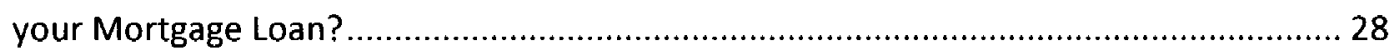

FIGURE 6: For how long have you been a Customer with your Bank? ........................ 30

FIGURE 7: Up to now Advice for Mortgage Loans is free with almost all German Banks. Could you imagine paying Money for that Service in the Future if so, for what Reason? ......... 31 FIGURE 8: How much Money are you willing to pay for a good, extensive Advice for Mortgage Loans? 33

FIGURE 9: Willingness to pay less than $100 €$; Individual Model versus Standard Model 34 FIGURE 10: Possible Consulting Fees in Savings Banks / Credit Union in contrast to the overall Result 35

FIGURE 11: Possible Consulting Fees in private Banks in contrast to the overall Result.. 36 FIGURE 12: Possible Consulting Fees depending on the Age of the Prospect. 37 FIGURE 13: Would you rather prefer contracting with a Bank that takes Money for Mortgage Loan Advising? 
FIGURE 14: Please imagine you could choose between two Types, an Individual Mortgage Loan Advice with Costs and a Standardized Model exempt from any Charges. Which one

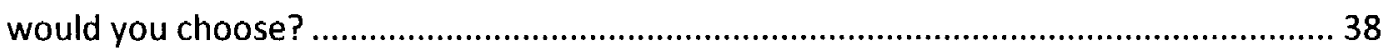

FIGURE 16: Question 8: How many different Bank Connections do you currently have? 39 FIGURE 17: Customer loyalty in Correlation to the Number of Bank Connections .......... 39

FIGURE 18: What are the Reasons for these different Bank Connections?....................40

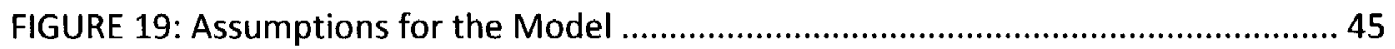

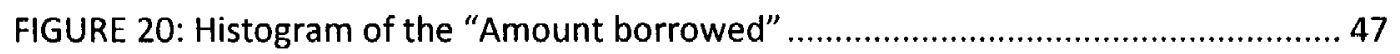

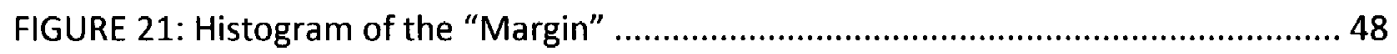

FIGURE 22: Histogram of the "Number of consulting sessions" per Year per Advisor..... 49

FIGURE 23: Histogram of the "Duration of Consulting Session" .................................. 50

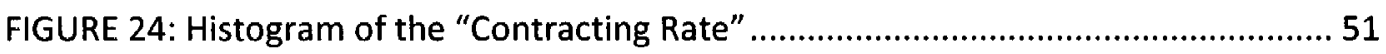

FIGURE 25: Estimated Revenue based on Consulting Fee " $0 €$ " (present state) ............. 52

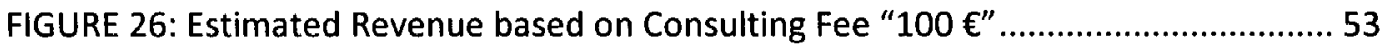

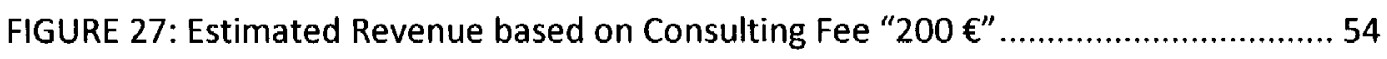

FIGURE 28: Estimated Revenue based on Consulting Fee "300 $€$ " ................................ 55

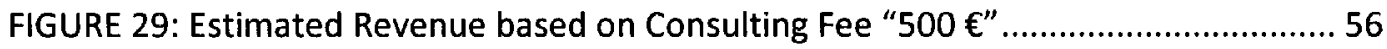

FIGURE 30: Estimated Revenue based on Consulting Fee - Overview.......................... 57

FIGURE 31: Probability of profitable mortgage loan consulting sessions....................... 58 


\section{INTRODUCTION}

\section{Motivation for Choosing the Topic}

In Germany and especially in the southern German area called Swabia there are some sayings that only if services have to be highly-paid, they are regarded as being worthy.

On the other hand exactly these Swabian people, amongst other groups of the German consumers, expect services to be free of any charges, because - in contrast to the above mentioned sayings - they are simply not aware of the interlink between costs and the offered services. Alas, as a matter of course, they expect high-quality services.

These two simple statements clearly show the dichotomy in German customer culture regarding the functioning of services. Hence, it is not surprising that a lot of services in Germany - if offered at all - are offered for free. However, most probably there is a high degree of cross-subsidization by the pricing of a product being linked closely to the service with adequate margins, to enable sustainable provisioning the services "for free" - at least from the customer's perspective.

The above explained thinking resulted in a trend of more and more customers seeking free advice at organizations that offer the above mentioned subsidized, i.e. "free", services but, after receiving the free service, purchasing products at the most inexpensive provider which, most often, has no sales and / or service organization and can thus provide lower prices than said subsidizing organizations. 
In the German market this "cultural" consumer trend could firstly be observed with electric goods and books (Amazon.de), later on with cars (Mobile.de) and many others. For instance, as far as books are concerned, many people still tend to make use of competent counseling services of up-front book stores and manually browse the exhibited books while planning to finally order a respective copy via Amazon.de or buch.de due to the lower prices or bonuses.

Today almost any goods and services are offered directly via the Internet. Prices are either highly transparent or can at least be compared on an international scale. Expectedly, this trend didn't even stop over with highly specialized services such as retail banking, especially mortgage loan banking.

Until today, the German financial market is dominated by commission banking. Beyond that, prospects are very price-sensitive. This mind-set was inter alia fostered by a very aggressive marketing strategy of the Media-Saturn / Metro Group: "Geiz ist geil" ("avarice is wicked"1). As a consequence, an increasing number of prospects adopted the following two-step approach: Firstly, seeking highly qualified consultancy of wellestablished retail banks where they can expect optimal consultancy for free, and, secondly, contracting with another bank, preferably a cheap internet bank ${ }^{2}$ which offers no consulting services at all, but offers more lucrative products and / or interest rates. Thus, the prospects profit from the good consultancy service while at the same time no countervalue is established for the consulting institution, since contracting decisions are solely made on the basis of the cheapest price, respectively the best interest rate, which leads the prospects to the non-consulting cheap direct bank.

\footnotetext{
${ }^{1}$ Cf. Appendix 1

${ }^{2}$ Also referred to as "direct bank" ("Direktbank") in Germany
} 
What most people ignore is that traditional banks with a conventional sales organization are just apparently more expensive than those without. If the sales-activity of the bank would be separated in firstly the consulting- and secondly the mere back-office or handling part, the activity would be more transparent and many customers would discover that their house bank is on a competitive basis with the direct bank. Thus, in separating the two above mentioned activities, the customer would be able to recognize why he is paying a higher prize with his house bank than with the direct bank. Thereby, the consulting part could be more appreciated in future. Especially this statement will be discussed later in this thesis in detail.

\section{Problem Discussion and Structure of the Work}

Up to now, as mentioned above, it is common in the financial sector in Germany to counsel clients and even potential clients for free. The provisioning of information, even rather elaborate financing concepts, by financial consultants to the customer is regarded as a complimentary service. This necessitates cross-subsidization of the consulting services by the price of the product.

Numerous recent investigations ${ }^{3}$ of well-established and independently operating consumer protection organizations such as "Stiftung Warentest" show that the consulting quality of banks and other financial service providers in Germany is very low. Why is that? Some say that bank consultants are salesmen for special products with high commissions rather than objective consultants. These "consultants" are only interested in op-

\footnotetext{
${ }^{3} \mathrm{Cf}$. http://www.test.de/themen/geldanlage-banken/test/Anlageberatung-von-Banken-Keine-beraetgut-1829939-1831738/ June, $14^{\text {th }} 2010$

The consulting quality of banks in Germany is very low. Only three out of 21 banks tested achieved "satisfactory" status, whereas none of them achieved "good" or "very good". Two out of the 21 banks failed completely.
} 
timizing their own salary by selling high-commission products no matter if these products actually fit the customers' needs.

The approach of pricing specific financial services has been discussed and considered for a long time in Germany, but up to now service-pricing is not applied in any bank by default. By now, consulting fees are only common in big private banks in the field of asset management of considerable private funds. Hence, consulting fees in mortgage loan banking are a real niche in Germany.

The thesis' contribution to this field of interest will be whether consulting fees in mortgage loan banking can be employed in the German market by now. For this purpose, an investigation on various aspects of mortgage loan banking has been conducted by means of a questionnaire ${ }^{4}$ which has been distributed to preselected participants. This investigation forms the second part of the thesis.

The third part presents a basic model for a Monte Carlo simulation evaluating the effect of consulting fees on potential revenues in the field of mortgage loan banking. It also presents an approach for a proper implementation of the new pricing strategy based on consulting fees in retail business for mortgage loans.

The last part comprises a summary of the major insights of this work and offers prospects for further research.

\footnotetext{
${ }^{4}$ Cf. Appendix IV
} 


\section{MAIN PART}

\section{Pricing in Banking}

Traditionally, German banks are rather conservative when talking about prices. They rather talk about dues, terms or agio but try to avoid the term "price" itself or what the price contains (Wuebker et al. 2006). This habit changed during the last years because markets became global and diaphanous, and prices, particularly of products and services, became the critical parameter of competition ${ }^{5}$.

\subsection{Traditional Pricing of Mortgage Loans}

Although banks have ever since oriented the interest rate of a mortgage loan according to the credit-worthiness of the customer, for a long time this was rather a subjective assessment of the bank-advisor for the pricing of the mortgage-loan ${ }^{6}$ instead of an established formula that could be verified by a third party.

Most often, the price / the interest rate was also calculated by intuition ("How much is the customer willing to pay?") and or by comparing the own interest rates with the main competitor (Wuebker et al. 2006).

With the introduction of the "Basel II Standard"7 in 2007, this changed dramatically, be-

\footnotetext{
${ }^{5}$ Appendix 2
}

${ }^{6}$ Credits were made by handsale on the basis of a long-establishes customer-bank-relationship with mutual trust and understanding.

${ }^{7}$ Basel II: Basel II is the second of the Basel Accords, which are recommendations on banking laws and regulations issued by the Basel Committee on Banking Supervision 
cause now, every customer who was rated according to the IRBA ${ }^{8}$-approach has its own objective rating. Such objective rating is obtained by performing the complete modeling, validation, statistical calibration and implementation of this approach in the same way for all customers. For that reason, each customer has its own POD which is comparable with the POD of others and which can be undermined with a certain spread on the credit margin. This led to a wide spread between good and bad credit-worthiness ratios of the customers. The above explained process enables the assignment of individual interest rates for mortgage loans of different customers, which accounts for their subjective risk situation.

However, the explained process does not provide for explicit pricing of consulting services; they are rather mingled in the price of the mortgage loan and result in an increased interest rate.

8 "IRBA" means "Internal Rating Based Approach", see $\$ 55$ SolvV (German law that provides for an adequate source of equity of German financial institutions) 


\subsection{Advantages and Disadvantages of Traditional Pricing}

Some of the disadvantages of conventional, i.e. free, counseling approaches have already been broached in the introduction.

Firstly, due to the effect of cross-subsidization, customers who do not require counseling at all also have to contribute to counseling costs. I.e., they cannot be offered a fair price for the product or service they require due to the cross-subsidization.

Moreover, most probably, since there is no well-defined price for counseling with the conventional approach, even bank counselors themselves may come to the conclusion that a frowsy, less accurate consultancy is good enough for a service that is for free. This is further supported by the informal style of counseling in the absence of counseling fees, since presently, there were only few requirements to document a counseling session. However, at least in the field of bond management, this problem has been addressed by German legislation, because since January $1^{\text {st }} 2010$ standardized, obligatory processes to document a consulting session ${ }^{9}$ have been defined.

Still further, due to the lack of transparency regarding actual costs that are being caused by receiving consultancy, many customers tend to excessively use or even exploit consulting services, which may also be denoted as "consultancy grazing".

From a corporate point of view, too, a lack of transparency regarding counseling activities is disadvantageous since a bank cannot obtain reliable data as to how much effort is actually spent for providing „free" consulting sessions.

\footnotetext{
${ }^{9}$ German Act Revising the Legal Relationship under Tranches of Debt Issues and Improvement of Enforceability of Investor Claims in the event of False Advice ("Gesetz zur Neuregelung der Rechtsverhältnisse bei Schuldverschreibungen aus Gesamtemissionen und zur verbesserten Durchsetzbarkeit von Ansprüchen von Anlegern aus Falschberatung")
} 
The above observations evidence several severe disadvantages of traditional pricing approaches which merely focus on the product itself while neglecting service aspects. Nevertheless, two advantages of the traditional pricing methods are apparent: Firstly, the bank has no effort in calculating a value for services that are offered "for free". Secondly, the simplicity of such model is attractive and easy to understand for customers. 


\subsection{Alternative to Traditional Pricing: Consulting Fees}

Since 1993 there are hints in literature that the consulting service of a bank advisor has to be priced as substantial part of the whole "product" (Eberstadt, 1993). Eberstadt emphasized this by pointing out that the advice given by a bank clerk has the same significance as the advice given by a lawyer or a tax advisor, i.e. a highly personal service.

An expert consultation conducted in 1994 among executives in retail business in banks showed that two thirds of them were convinced that up to the year 2010 there will be major changes in the pricing policy (Severidt, 2001). There is evidence in 2009/2010 that this might be true, because there are a lot of articles printed in trade press dealing with this issue in the last months, but a real breakthrough of this topic is still out of sight (Baulig, 2010; Schmidt, 2009). 


\subsection{Different Structures of Consulting Fees}

As there is hardly any material in literature on consulting fees in mortgage loan banking, the following observations dealing with possible structures to determine the height of consulting fees are derived from the neighboring field of asset management. In chapter 3.5, some of the insights of chapter 1.4 are transferred to the field of consulting fee pricing in mortgage loan banking.

\subsubsection{Quantitative Differentiation}

According to Eberstadt (Eberstadt, 1993), consulting fees can be determined based on the actual duration of a consulting session. Similarly to lawyers or tax consultants, the resource "time" is charged. Obviously, this model is based on the principle of causation. Each cost unit carries the costs which were actually caused. According to this statement, each consulting hour has to be priced adequately. For the details of pricing of one consulting hour see chapter 1.6.

A major disadvantage of this method might be that customers having a low amount borrowed might not be willing to pay high consulting fees, which in fact could result from complex mortgage loan structures regardless of the amount borrowed. Thus, the quantitative approach could lack customer acceptance especially for low credit amounts.

For this reason, an option would be to provide three separate models of quantitative differentiation, e.g.

a) easy consulting process and small credit amount,

b) moderate complexity of consulting process, and

c) high complexity of consulting process,

wherein for each of these cases different hourly wage rates may be assumed. 
The difficulty with these categories might be that "easy, moderate and complex" are very subjective terms and the customer would probably try to get in a lower category, i.e. range of hourly wage rate, by claiming that his mortgage loan is of low or moderate complexity. Hence, for successfully implementing the above categories, clearly defined criteria for the different categories are a prerequisite.

A further disadvantage of the quantity-related model is the increased administrative effort (measuring time, categorizing, detailed billing etc.) of the bank. Moreover, customers could demand a really short advice, in order to save money, thus turning the consulting principle into absurdity, because they either get an information overflow or the quality of advice is poor ("quick and dirty"). Furthermore, a confiding relationship to the bank advisor cannot be established within a short time though being essential for gaining customer loyalty. This aspect, on behalf of the bank, could also be considered as an advantage, because if customers are less time consuming, the bank can save money by reducing their sales-personnel in the mid and long run.

The most essential disadvantage with quantitative differentiation, as with any other form of paid consulting services, too, is the increased probability of the customer changing banks easily, because he only occasionally asks for specific advice reducing his tendency to rely on standard products of the bank.

To mitigate this effect, volume discounts may be introduced for consulting hours or even prepaid flat rates as it is commonly accepted in telecommunication. Such prepaid consulting hours could also be bundled with standard products. 


\subsubsection{Performance-Related Differentiation}

According to Severidt (Severidt, 2001), another possibility to price a service could be the performance-related price-differentiation, wherein the value of the consulting performance is measured by means of the attained annual rate of return. As a result, the customer only pays a certain portion of this attained annual rate to the bank. One major advantage of this method for the client may be that only such banks will offer a service that are convinced of their own high performance to attain high annual rates of return. Although highly promising for the customer, the bank itself has a huge effort in setting an equitable assessment basis as well for the attained annual rate of return as the income compensation function. Thereby, the annual rate of return for the customer always has to be regarded in the context of the whole market development and / or the risk the customer has had with his investment ${ }^{10}$. In Germany, this model is predominantly found in asset management, where the asset manager is the person to decide which assets to buy and not the customer. This is because if the customer had influence on the asset to buy, the bank wouldn't have a real influence on the rate of return. The implementation of this model is really rare in Germany, because the complete risk to perform is situated with the bank.

\subsubsection{Volume-Related Differentiation}

With this model, the customer would pay a pre-fixed amount of money only depending on the credit volume of his mortgage loan. This form of payment would particularly be independent of the complexity of the loan structure.

An advantage of this model would be that customers are familiar with this type of pricing, e.g. from stock transactions etc.

\footnotetext{
${ }^{10}$ For example: The risk of a savings deposit is almost zero, thus, the annual rate of return is comparably low in contrast to a high-risk Argentinian bond-option.
} 
The volume-related differentiation could also be structured with different fees according to the absolute height of the amount. For example:

TABLE I

VOLUME-RELATED DIFFERENTIATION

\begin{tabular}{|l|l|}
\hline$<100,000$ & $0.5 \%$ \\
\hline$>100,000$, smaller than 400,000 & $0.4 \%$ \\
\hline$>400,000$ & Individually, at least $0.2 \%$ \\
\hline
\end{tabular}

\subsubsection{Multi-Channel Pricing}

More and more customers vary their habits of contacting their bank. They no longer prefer to visit one of the subsidiaries to personally meet their advisor but rather tend to use different channels like telephone, Internet etc. (Wuebker, 2006). According to the different channels, it might be interesting to set up different prices for accessing these channels. E.g., the consulting fee for the advice via Internet or telephone may be cheaper than personal contact with a special advisor.

\subsubsection{Advantages of Consulting Fees}

There are according to Meyer (Meyer, 2006) some major advantages of consulting fees.

The first one is consumer acceptance. By dividing the price into two components, i.e. a service component and a product component, the customer becomes aware of the true value of the consulting service, which increases his willingness to pay the price. Further, for the bank advisor, consulting is no longer a mere means to get provisions but the center of his sales activities. The consulting fees thus adapt the customer's needs for a 
high-quality advice to the advisor's need to earn money for the bank, which serves to alleviate an initial suspiciousness on both sides.

The second aspect is enhanced objectivity. The original task of a bank advisor is to generate return for his bank. This sometimes does not meet the customer's requirements because in some cases it might be better for the customer to do nothing instead of buying any other product he doesn't really need. Therefore, if the income of the advisor would already be generated by the counseling process, and not only by contracting, the advisor had a minor interest to sell products with a high margin (Bernet, 1996). I.e., the pressure to sell useless products would be reduced, which fosters mid-term customer loyalty.

The third aspect is the enhanced awareness for the "product" consulting service. Currently, a lot of banks try to differentiate themselves by the most melodious product names and their prices in order to waken customer's needs. And although every bank is convinced of their high consulting quality, e.g. "Deutsche Bank - Leistung aus Leidenschaft" ("Deutsche Bank - performance made of passion"), this attribute has only been of minor importance up to now. By pricing the consulting, the service itself is spotlighted and thus more attractive for customers. Moreover, quality differences can be made more obvious. In this context, the transparency of costs is another advantage of consulting fees for the customer and the bank, because it makes the costs of the service explainable to the customer which again goes along with more confidence in the bank.

Another positive aspect of consulting fees could be the possibility for tax deductibility. For instance, it would be interesting for customers who plan to buy a condomi- 
nium in order to rent it out afterwards, to generate high tax deductibility with the consulting fees.

Last but not least, consulting fees make it much easier for the customer to change the contractor, because there are no psychological barriers such as a bad conscience due to having received free advice. The danger of free-riders is extremely reduced.

\subsubsection{Disadvantages of Consulting Fees}

Lack of sales incentive: If the focus is no longer on selling commission-based products, sales consequently go down. And, congruously, due to a more objective advice, less provision-oriented products are sold. Therefore, the return generated of the highmargin products diminishes and has to be absorbed by the returns generated through the consulting fees.

Secondly, the cross-subsidization of products / services becomes more complicated or even dies away completely because of the high market transparency. The major disadvantage here is, that banks have to "justify" their prices. Where they were once able to sell a whole non-transparent bundle (product and service), they are now forced to reveal the price components in detail.

Thirdly, there may be an inhibition threshold for some customers to seek a second opinion and to compare products or even to be advised at all. Thus, the advisor no longer has the chance to identify the customers' need on a personal and informal basis such as a free advice, because the customer doesn't show up in the advisor's office. In this context, cross-selling potential, too, might die away. If the customers' needs are not urgent, they no longer feel the need of paying for something they do not require. 
Another aspect is that retail banks must fear public reactions, for the pricing of banking products in general is of high public interest. As a matter of cause, the pricing of banking products must be justified more often than products or services of other industries. In order to reduce these reactions, retail banks should precisely point out why they introduce consulting fees. The introduction should always be accompanied by e.g. a rise in consulting quality and/or the lowering of administration fees, credit interest rates and transaction costs (e.g. remittances). So it becomes clear to the public that these products formerly have been massively cross-subsidized.

Another reaction could be evoked by the competitors. The banking sector is oligopoly which means only a small numbers of big retail banks and a mass of private customers. Due to high price pressure amongst the banks, it is really challenging for one of the institutions to make public apparent price raises. Due to this, consulting fees would be unsustainable unless

- All institutions would raise consulting fees or

- Consulting fees come along with higher consulting quality or

- The Introduction of consulting fees cross-subsidize the decline of transactional costs or interest rates

(Severidt, 2001). 


\subsection{True Value of a Mortgage Loan Consulting Service}

Later on in this thesis, for the Monte Carlo Simulation part (chapter 3), it is important to know what the real expenses for a bank for a mortgage loan consultancy are.

This "true value" of a mortgage loan consulting service can be calculated with help of the following tables. They take into consideration the various procedural steps in the course of consulting. The duration in minutes of the respective steps were determined by expert questioning.

TABLE II

PROCESS STEPS AND DURATION OF AN EXTENSIVE MORTGAGE LOAN CONSULTANCY (WORST CASE APPROACH)

\begin{tabular}{|c|c|}
\hline Process Steps for an already existing Customer & Duration in min \\
\hline Scheduling an appointment (via telephone, E-Mail etc.) & $\mathbf{8}$ \\
\hline Preparation of appointment & $\mathbf{4 7}$ \\
\hline Research & 5 \\
\hline Arrange customer information (via electronic devices) & 4 \\
\hline Prepare presentation & 22 \\
\hline Print and bind presentation & 4 \\
\hline Ask and prepare questions of the credit analyst & 8 \\
\hline $\begin{array}{l}\text { Pre-Calculation for an offer (if known afore the appoint- } \\
\text { ment) }\end{array}$ & 4 \\
\hline Conduction of appointment & $\mathbf{1 1 9}$ \\
\hline Travel time & 21 \\
\hline Conduct appointment & $\mathbf{7 2}$ \\
\hline Appointment - Follow Up Process & 98 \\
\hline
\end{tabular}




\begin{tabular}{|l|c|}
\hline Documentation of appointment results & 10 \\
\hline Start advised processes & 12 \\
\hline Identification of cross-selling potential & 9 \\
\hline Analyzing customer documents & 39 \\
\hline $\begin{array}{l}\text { Determine new product price (e.g. recalculation of the offer; } \\
\text { new calculation according to the customer's needs) }\end{array}$ & $\mathbf{7}$ \\
\hline \multicolumn{2}{|c|}{$\mathbf{2 5 3}$ min $=\mathbf{4}$ hours and 13 minutes } \\
\hline
\end{tabular}

TABLE III

ADDITIONAL PROCESS STEPS FOR NEW CUSTOMERS

\begin{tabular}{|c|c|}
\hline Additional Process Steps for a new Customer & Duration in min \\
\hline New customer: Additional processes & 17 \\
\hline Check, if customer already exists in electronic data base & 2 \\
\hline If not, apply new customer & 3 \\
\hline Apply new personal data and address & 2 \\
\hline Check legal requirements if necessary & 2 \\
\hline Apply new subscription of customer & 8 \\
\hline Pre-Calculation of product price on the basis of raw data & 7 \\
\hline $\begin{array}{l}\text { Conduct first advice via telephone including first introduction } \\
\text { of the advisor oneself }\end{array}$ & $\mathbf{3 0}$ \\
\hline Sum & \multicolumn{2}{|c|}{$\mathbf{5 4}$ minutes } \\
\hline
\end{tabular}

To summarize: The "worst case" effort for a bank with an already existing customer for a mortgage loan consultancy is about 4 hours. If the customer is new, the effort of 
the bank / the consultant rises by approximately one hour, which means 5 hours of consulting and administrative effort in sum.

To calculate the costs per hour, respectively the cost per given advice, the labor costs and their composition have to be calculated.

The basis of Table IV is the collective labor agreement in "Tarifvertrag des privaten Bankengewerbes in Deutschland"11. Each employee has to work 7 hours and 48 min a day within around 230 working days per year (vacation already subtracted). In sum, these are 1,794 working hours per person per year.

In combination with Tables II, III, it can be determined, how much an average consultancy of a mortgage loan really costs.

\section{TABLE IV}

DETERMINING THE LABOR COSTS PER HOUR OF A BANK ADVISOR

\begin{tabular}{|l|r|}
\hline \multicolumn{1}{|c|}{ Component } & \multicolumn{2}{c|}{ Costs in $€$} \\
\hline Salary (Per year) & 60,000 \\
\hline Ancillary labor costs (Additional 20\% of the salary) & 12,000 \\
\hline Support (Secretary, assistant, back office etc.) & 25,000 \\
\hline $\begin{array}{l}\text { Work place (Lease, heating, office equipment, company } \\
\text { car, etc.) }\end{array}$ & 15,000 \\
\hline $\begin{array}{l}\text { Electronic devices (Computer, licenses, telephone, mobile } \\
\text { phone) }\end{array}$ & 10,000 \\
\hline Advertisement & 1,000 \\
\hline Overhead (Brochures, gifts, events etc.) & 1,000 \\
\hline Sum & $\mathbf{1 2 4 , 0 0 0}$ \\
\hline Costs for 1794 working hours (230 days) & 124,000 \\
\hline Costs for 1 hour & 69.12 \\
\hline
\end{tabular}

${ }^{11}$ Collective labor agreement of private bank sector in Germany 


\begin{tabular}{|l|r|}
\hline $\begin{array}{l}\text { Costs for the mortgage loan advice for an already exist- } \\
\text { ing customer }\end{array}$ & 291.69 \\
\hline Costs for the mortgage loan advice for a new customer & 353.89 \\
\hline
\end{tabular}

For the Monte Carlo Simulation Part, it is necessary to split the above listed costs into variable costs and fixed costs, as presented by Table V.

As fixed costs only those costs are considered that exist, no matter if the advisor is employed or not. As variable costs only the real labor costs are considered.

\section{TABLE V}

FIXED COSTS VERSUS VARIABLE COSTS

\begin{tabular}{|l|l|l|l|}
\hline \multicolumn{1}{|c|}{ Fixed costs } & \multicolumn{1}{|c|}{$\begin{array}{c}\text { Amount in } \\
\text { EUR }\end{array}$} & \multicolumn{1}{|c|}{ Variable Costs } & \multicolumn{1}{c|}{$\begin{array}{c}\text { Amount in } \\
\text { EUR }\end{array}$} \\
\hline & & Salary per year & 60,000 \\
\hline Support & & Ancillary Labor costs & 12,000 \\
\hline Workplace & 25,000 & & \\
\hline Electronic devices & 15,000 & & \\
\hline Advertisement & 1,000 & & \\
\hline Overhead & 1,000 & & $\mathbf{7 2 , 0 0 0}$ \\
\hline Sum: & $\mathbf{5 2 , 0 0 0}$ & & $\mathbf{4 0 . 1 3}$ \\
\hline Costs for one hour & $\mathbf{2 8 . 9 9}$ & & \\
\hline
\end{tabular}




\subsection{Summary}

Although numerous studies show (Baulig, 2010) that bank managers are convinced that consulting fees will play a major role in future, banks will have difficulties in introducing the new model, which is based on consulting fees, because for almost all German banks it is a new business concept.

The following aspects should be taken into consideration when implementing consulting fees:

- Advantageously, the consultant is independent because he is not influenced by the need of maximizing his / her own salary. Hence, he has a sustainable consulting approach based on the economic well-being of his customer.

- The consulting fee paid is adequate for the provided consultancy service, particularly for the provided special know-how and time of the consultant.

- The consulting fee is transparent and free of any third party commissions. 


\section{Empirical Study and Results}

\subsection{Structure and Conduction of the Study}

The questionnaire used for the study contains twelve questions relating to consulting fees in mortgage loan banking (Appendix IV) and was distributed in March and April 2010 to about 260 people, whereof 96 people replied within the deadline. Thus, the return rate is about $37 \%$, which is comparatively high for an empirical study based on a questionnaire. The 260 participants of the study represent no arbitrary cross-section of the population; they rather constitute a pre-selected sample of mainly people with higher education and special knowledge of economic principles (e.g. business economists, economical engineers, business people, jurists and bank employees). The target group of the questioning comprises friends, colleagues, students at the author's former university and family members. This pre-selection was useful in that it narrowed the target group of people interested in mortgage loans to a certain degree. Further, the target group most probably represents a cross-section of what is considered as typical middle-class households in Germany. This represents the mortgage-loan prospects of banks sought after.

The questionnaire was provided in two languages, German and English, with identical content. Most people handed back the German version. The questionnaire was predominantly distributed via E-Mail and to a minor degree manually. Filled in questionnaires were returned in an anonymous fashion.

Some of the questions have multiple answers, if reasonable. This is why the sum of percentages may be more than $100 \%$ (on the basis of 96 replies), which is actually the case for all of these questions, i.e. numbers $1,2,4,5$ and 9.

All other questions (numbers $3,6,7,8,10,11$ and 12) only allowed a single choice. In these cases, too, the sum of percentages sometimes does not amount to $100 \%$ (e.g. 
$99 \%, 98.7 \%)$. This is due to the fact that not all questionnaires were properly answered. Some interviewees obviously forgot to answer one or more questions. If the answer rate was not too low, however, these responses were considered, too.

Only three responses did not meet the author's expectations as to proper answering and were not considered for analysis at all.

\subsection{Social Structure of the Target Group}

Question numbers 10,11, 12 are related to social parameters of the target group. Below, the results of these questions are discussed to provide information on the social structure of the interviewees prior to dealing with material aspects of consulting fees in the field of mortgage loan banking.

\subsubsection{Age Pattern of the Interviewees}

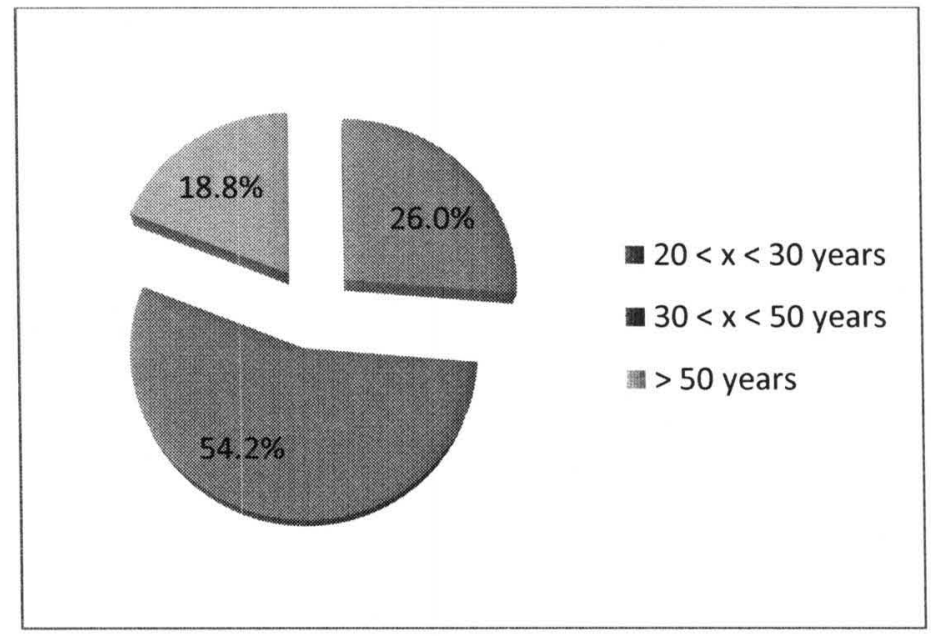

FIGURE 1: Age Pattern; Results of Question Number 10

The majority of interviewees are aged between 30 and 50 years, i.e. the preferred target group for mortgage loans, whereas only about one fifth is older and about one quarter lies between 20 and 30 years. 
Please note: In the course of the investigation, no responses from people below the age of 20 were received. Therefore, this group is not depicted in the diagram of Figure 1.

\subsubsection{Marital Status of the Interviewees}

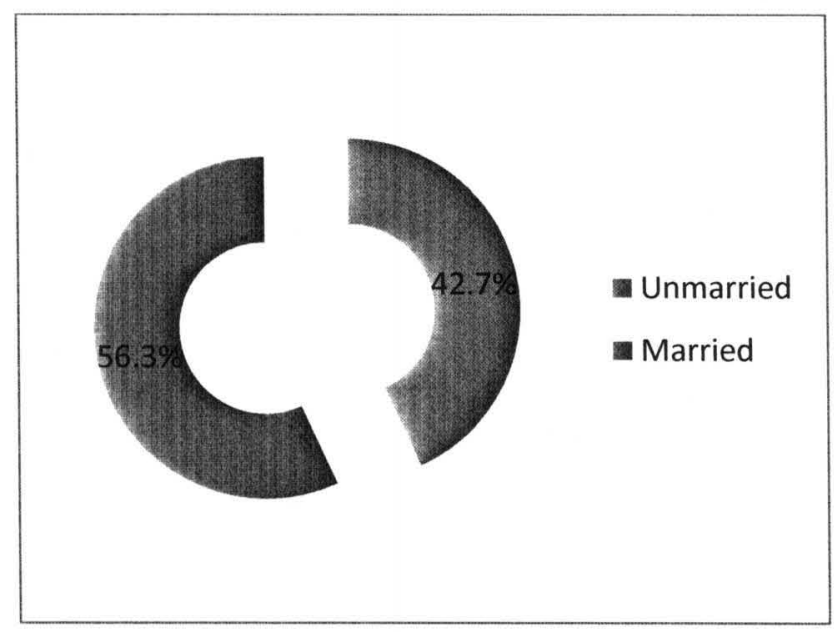

FIGURE 2: Marital Status; Results of Question Number 11

The distribution of the participants in the study is almost equal.

Moreover, a correlation between marital status and the answering of the following questions related to consulting fees could not be detected by reviewing a plurality of samples. 


\subsubsection{Occupation Group}

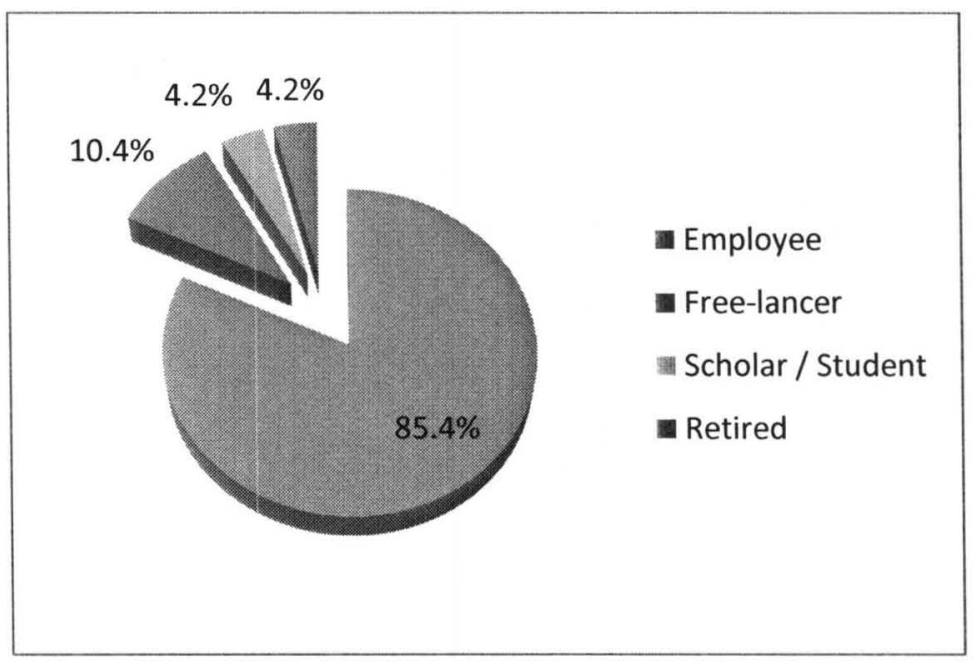

FIGURE 3: Occupation Group; Results of Question Number 12

Most of the people questioned in the survey are employees. The graph of Figure 3 thus properly reflects the overall structure of German working society. 
2.3 Questions and Results related to Mortgage Loan Banking and Consulting Fees in $\underline{\text { Detail }}$

\subsubsection{Question 1: Category of Financial Institution}

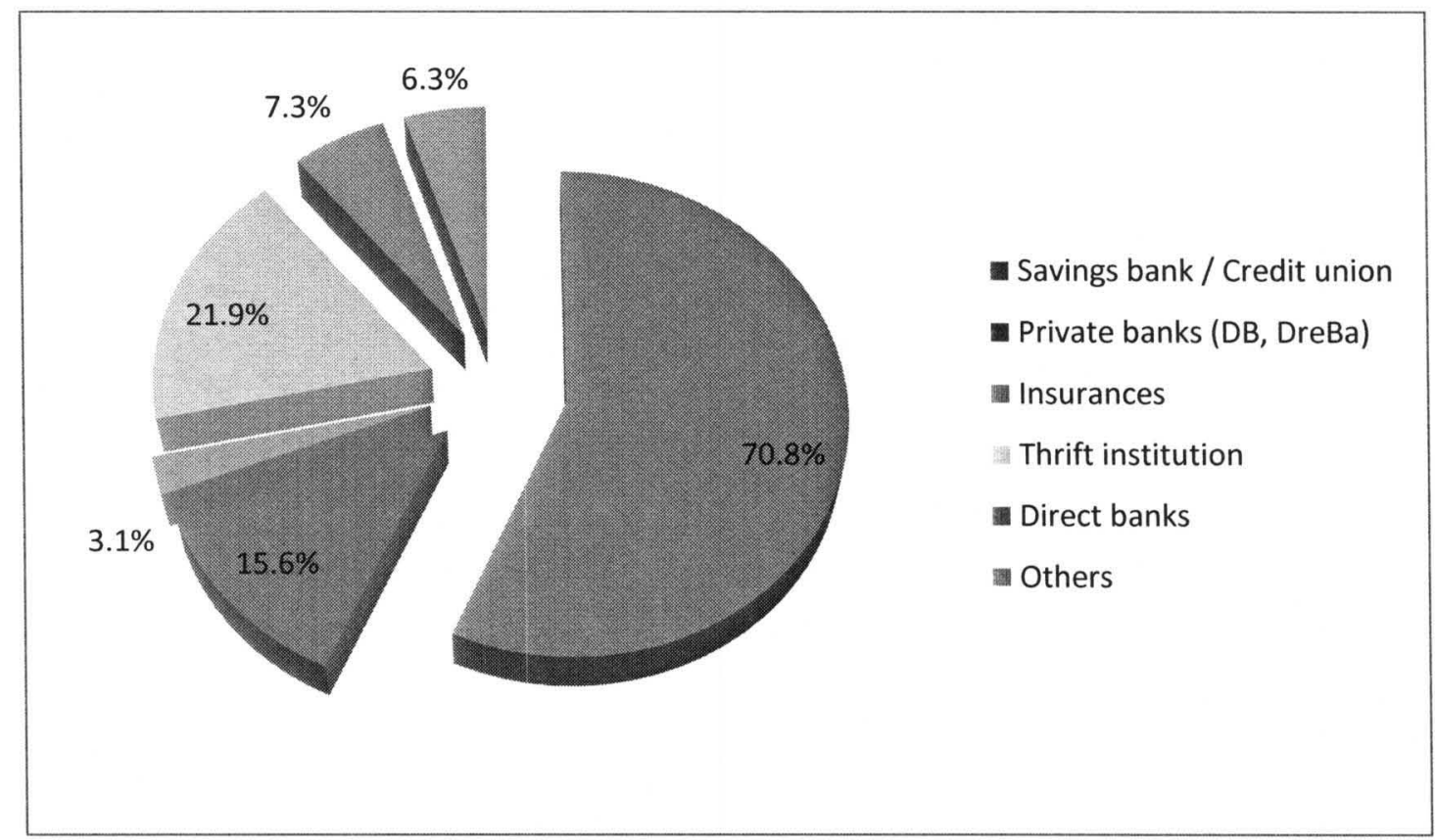

FIGURE 4: Which Category of Financial Institution does the Bank belong to where you concluded your Mortgage Loan Agreement / which Category of Financial Institution do you plan to choose for contracting your Mortgage Loan?

What is really interesting about this graph is the fact that savings banks and the credit union play, with a quota of almost $3 / 4$, a dominating role in the mortgage loan sector. This is due to the fact that these institutions have their focus on their customers. This criterion, as it will be obvious later when discussing question number 9 , is still a very important one.

The second largest part of providers is represented by thrift institutions. Notably, savings banks / credit union and thrift institutions were often listed in combination in the questionnaires, whereas combinations of thrift institutions and other providers only play a minor role. 
The predominance of the combination of savings banks / credit union and thrift institutions really makes sense for the customer. Why is that? In Germany, retail banks provide special, usually extremely low, interest rates for mortgage loans. This is by reason that these mortgage loans are secured by a residential property charge, most often in combination with a life insurance. As a result, the POD of the involved retail banks is rather low. The height of this "cheap" mortgage loan is strictly limited to at most $80 \%$ of the value (purchasing / construction costs) of the property. The overall duration of such a mortgage loan is up to 30 years with a minimum annuity of $1 \%$ at the beginning. For those cases, in which the customer requires between $80 \%$ and $100 \%{ }^{12}$ of the property value as loan, he will have to find further credit institutions to finance the remaining up to $20 \%$. In this context, thrift institutions offer a solution in form of a further mortgage loan with comparatively low interest rates. They also want to be secured by the same residential property charge but they subordinate their claim behind the savings bank / credit union. To compensate this effect, they claim higher annuities from their customers, up to $8 \%$ a year.

A further insight obtained from the diagram of Figure 4 is that private banks only pay a minor role, which might be due to primarily being regarded as the banks of corporate clients or the preferred bank for people not depending on mortgage loans. Often, private banks are also regarded to be the right choice for investment purposes, but not for (private) credit purposes.

Last but not least, a somewhat surprising aspect of Figure 4 is that direct banks only play a minor role in mortgage loan business even though they regularly offer the lowest

\footnotetext{
${ }^{12}$ Receiving more than $100 \%$ as a mortgage loan, as is possible e.g. in the USA, is not possible in Germany.
} 
interest rates of all mentioned institutions, which is in contrast to the above-discussed distinct price-sensitivity of German mortgage loan prospects. However, as the answers to question number 2, which are discussed in the following chapter, will show, price is in fact a really important factor but not the dominating one. The most important factor turned out to be the "main bank".

\subsubsection{Question 2: Reasons for contracting with a specific Bank}

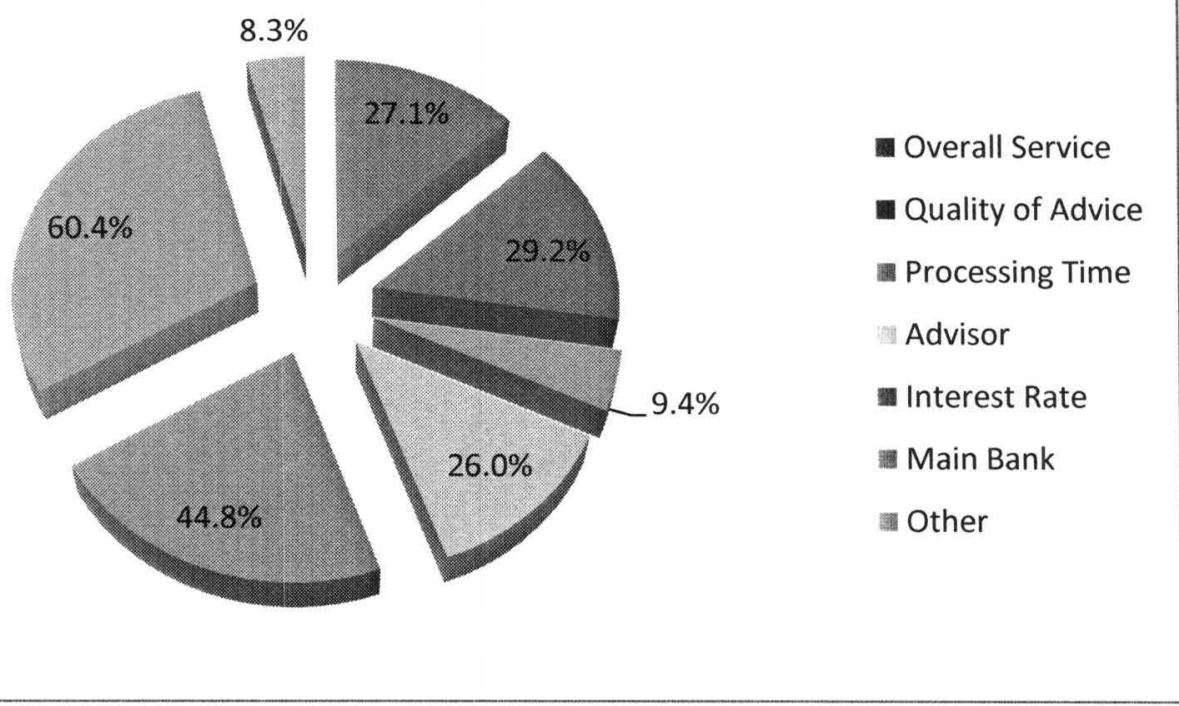

FIGURE 5: Why exactly did you choose / do you plan to choose that Bank for contracting your Mortgage Loan?

This graph, above all other results, shows the strong binding of German customers to their main bank. The statement of the graph is that almost two thirds of the customers stick to their main bank for mortgage loan purposes. In the author's opinion, this factor makes other aspects of the consulting process take a back seat, even such factors which are more tangible e.g. due to their cost-intensive nature (processing-time or advisor) ${ }^{13}$. The author is also convinced that a lot of banks are oblivious to this fact and waste a lot

\footnotetext{
${ }^{13}$ The author acknowledges that - at least to some degree - further "influences" for the main bank loyalty may exist, such as convenience.
} 
of money and time in improving the above mentioned tasks of minor importance instead of investing money in fostering and maintaining the customer-bank relationship, which according to Figure 5 presumably yields the best leverage effect.

Moreover, according to the author's knowledge, German banks primarily invest in quality and price, which necessitates considerable marketing expenses because all other competitors invest in that area, too. However, Figure 5 of the study shows that these factors are ranked only second and third.

Obviously, what the customer really wants is a stable, reliable and secure financial partner for the "whole life", which is embodied by the depicted loyalty to his main bank. The long maturity of mortgage loans (regularly up to thirty years) further supports the customer's wish for stability.

The following strategic ideas can be derived from the analysis of Figure 5:

1. Banks should spend more money to foster and maintain the customer relationship, i.e. by creating special products for their loyal customers ${ }^{14}$.

2. Secondly, due to the importance of low interest rates as evidenced by Figure 5 , banks should invest in creating strategies to lower the overall prices and costs to be able to offer such lower interest rates ${ }^{15}$.

Moreover, service and quality of advice also play an important role, each of them counting with about $28 \%$.

Regarding the advisor's importance as far as question number 2 is concerned, it is surprising that the person of the advisor obviously only plays a minor role in the contract-

\footnotetext{
${ }^{14}$ Promising models may e.g. be based on offering better interest rates and/or better maturities for loyal customers. Well-established customer loyalty programs of other industries could also serve as a basis for such models (e.g. frequent flyer programs).

${ }^{15}$ In this context - as already mentioned above - a fortiori, it astonishes that cheap direct banks play a minor role in mortgage loan activities.
} 
ing context (26\%), although the process of advising can be considered as a highly personal service on the basis of mutual confidence. This brings the author to the conclusion that people and advising services in their area of responsibility are exchangeable. I.e., it is not the people that make customers loyal to their bank. Supposedly, there are more important factors that the personal factor.

Another surprising effect derived from Figure 5 is the lack of importance regarding processing time, which direct banks are known for due to their lean structures. Nevertheless, due to the lack of significance of processing time as a competitive factor in mortgage loan consultancy, direct banks cannot profit from it in this area.

\subsubsection{Question 3: Customer Loyalty in Terms of Time}

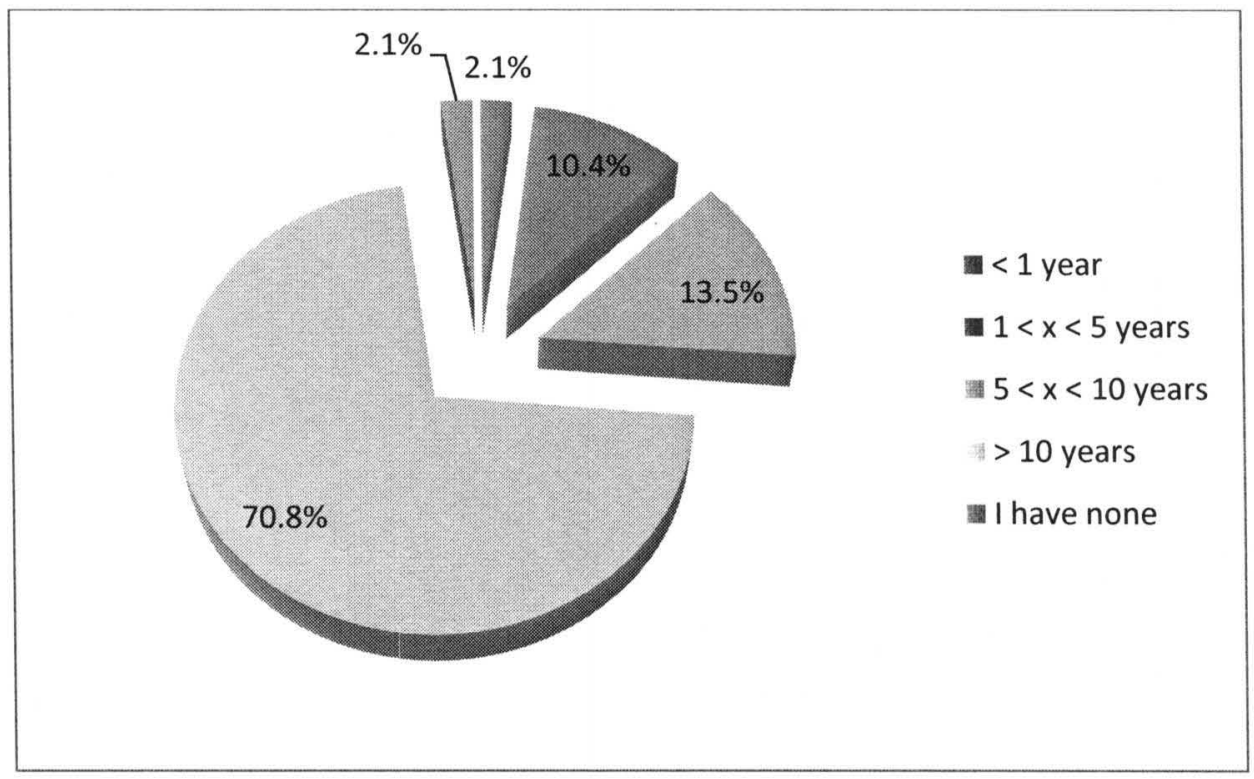

FIGURE 6: For how long have you been a Customer with your Bank?

The result of this question encourages the findings of question number 2 . Almost $3 / 4$ of the interviewees stick to their main bank for more than 10 years. This is all the more impressive when considering the age pattern of the participants, see chapter 3.2.1. Over 
$80 \%$ are younger than 50 years and a major group of those people maintains a long-term relationship to their main bank. In combination with the green piece of pie, which represents mid-term relationships between 5 and 10 years, almost $85 \%$ stay with their main bank for 5 years and longer.

\subsubsection{Question 4: Possible Reasons for paying for a Service}

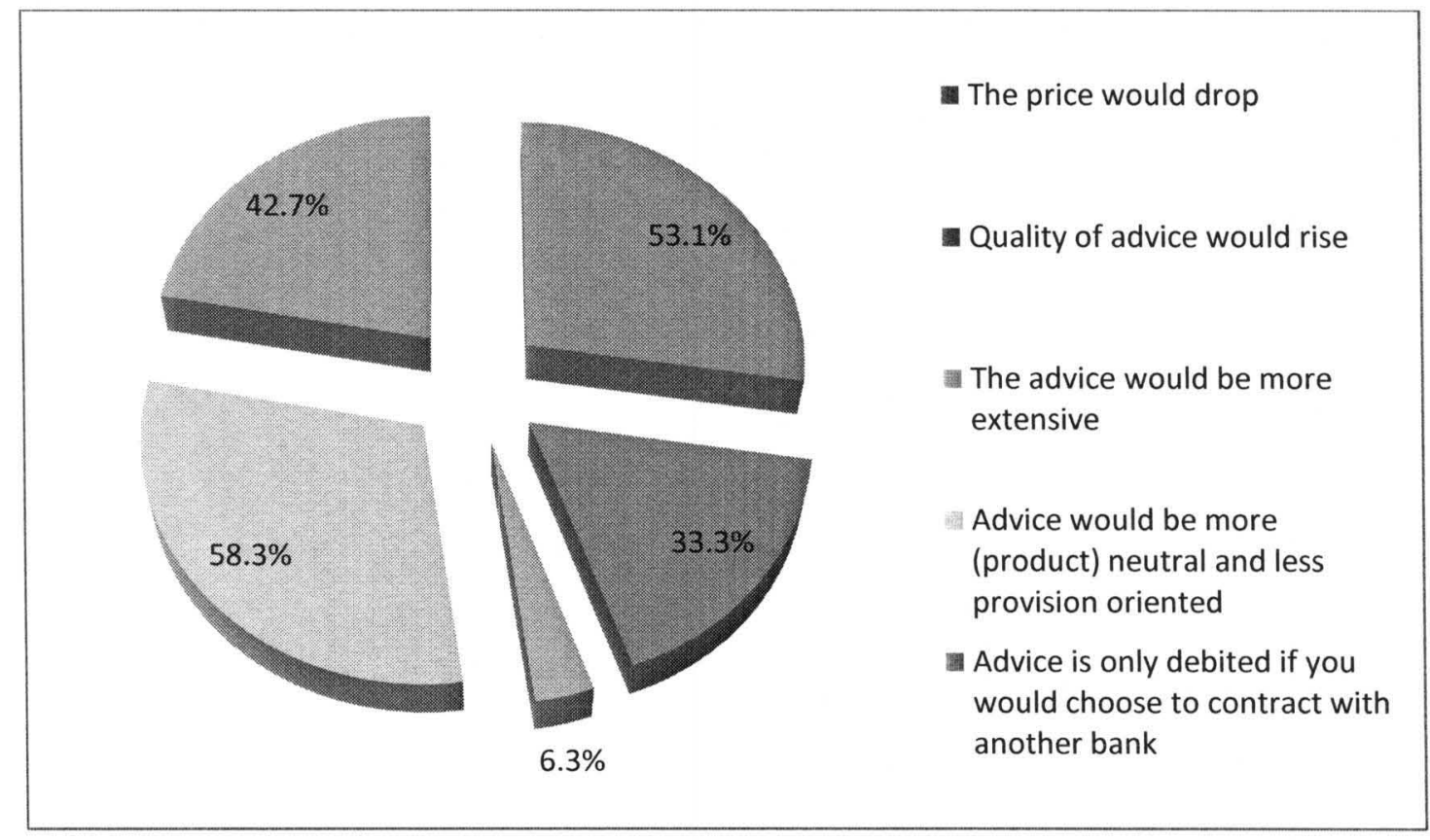

FIGURE 7: Up to now Advice for Mortgage Loans is free with almost all German Banks. Could you imagine paying Money for that Service in the Future if so, for what Reason?

This question was aimed to ascertain the customer's further requirements if he should pay for a service in the future which was for free until now. The astonishing result is that in the present context, as in contrast to question number 2, price is not the dominating factor (though highly important) but "a more product neutral and less provision oriented" approach in giving advice to the customer. One reason for that result might be the bad news releases bankers generally face in Germany since the global financial crisis. 
Currently, German media unequivocally constitutes that, in order to supplement their income, bankers only sell those products with high provisions no matter what the customer's need really is. According to the author's opinion there are, like in every branch of economy, some rotten apples, but of course, the above mentioned situation is not the general habit of bankers.

Another reason for the high demand for product neutral advice certainly is the lacking comparability of per se "plain vanilla" banking products. Of course, every bank offers checking accounts and mortgage loans. Unfortunately, every bank provides individual euphonic names for the plain vanilla products thus obstructing the customer's view on the services rendered and consequently impeding price comparisons.

The next important criterion is, as could already be expected, the price component. People want to have cheaper "products" (in this case the mortgage loan) if they pay a price for the service additionally. Thirdly, they want to pay the additional service fee only if afterwards they choose contracting with another bank.

Especially the latter offers the possibility to introduce consulting fees in the German mortgage loan market. According to the American saying "There ain't no such thing as a free lunch", every prospect should be aware that a highly complicated service can no longer be offered for free. Therefore, he needs to pay for the service. If he contracts with the bank that offered the service, he has either the chance to get his money refunded or the payment should be taken into account by the bank when calculating the (lower) interest rate. In the last part of this thesis, the author provides a brief outlook of how this strategy could be implemented. 


\subsubsection{Question 5: Height of Fees for Mortgage Loan Consultancy}

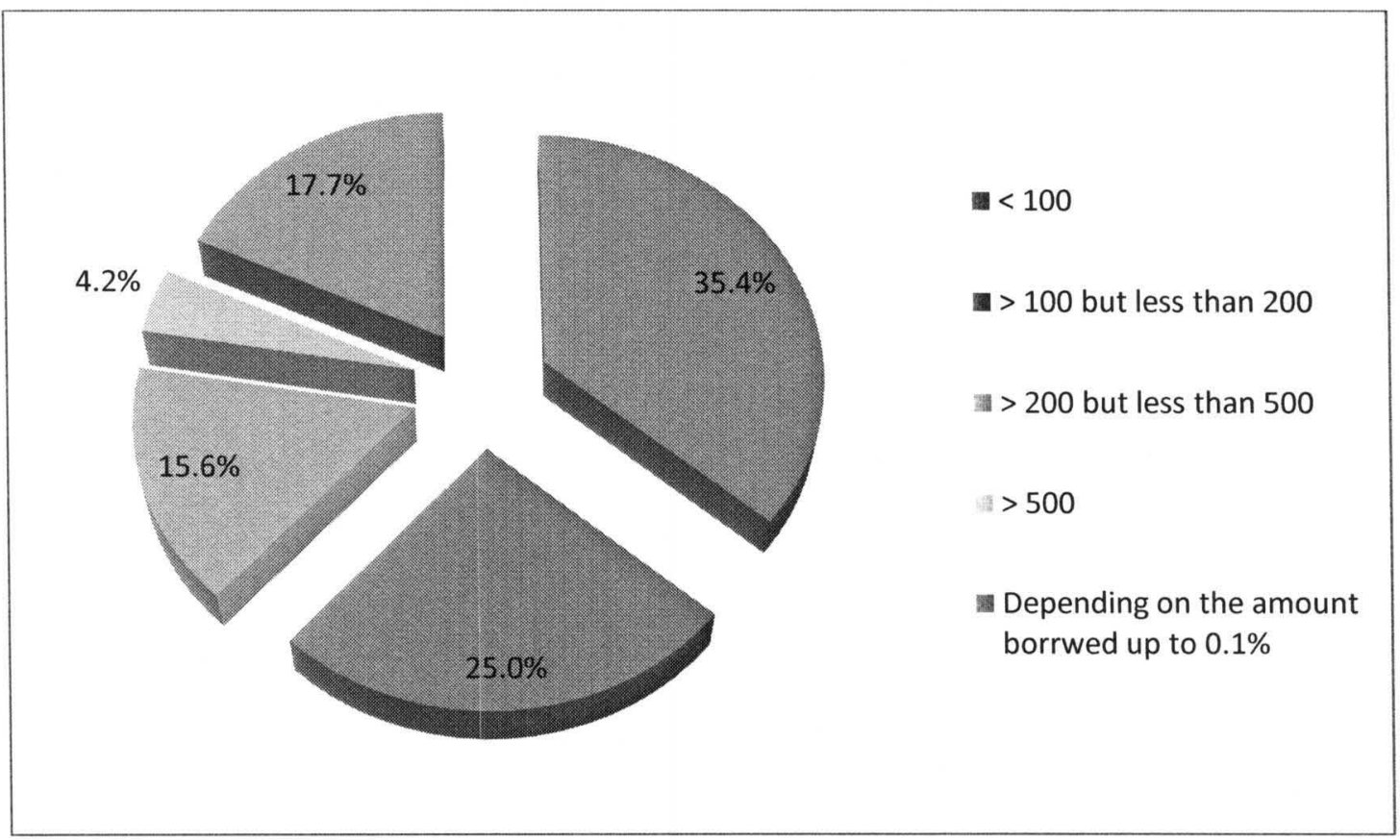

FIGURE 8: How much Money are you willing to pay for a good, extensive Advice for Mortgage Loans?

As could already be apprehended in view of the importance of low prices, a considerable group of about 35 percent of the respondents are only willing to pay up to $100 €$ for a mortgage loan consultancy, which is only a fractional amount of the whole consultancy effort ${ }^{16}$. Moreover, the "up to $100 €$ " class of response also includes the case of zero, for there are a lot of respondents who are not willing to pay any money for the consultancy ${ }^{17}$. The more interesting is the fact that those are predominantly the group that is more in favor of the standardized model (Figure 9).

${ }^{16}$ Cf. Table IV

${ }^{17}$ A future version of the questionnaire could be improved by adding a separate field of choice which covers the "zero" option. The author has been notified in writing by numerous respondents on their nonwillingness to pay any money. 


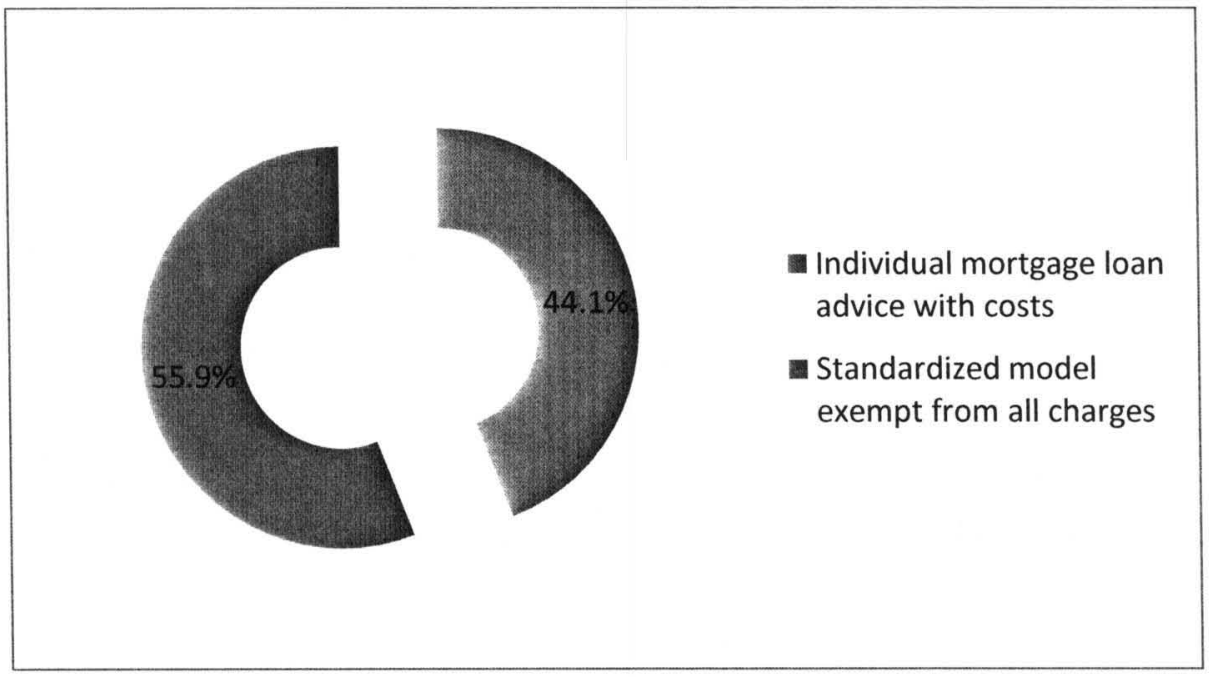

FIGURE 9: Willingness to pay less than $100 €$; Individual Model versus Standard Model

Only very few are willing to pay $500 €$ and more, i.e. an amount which comes close to the actual costs, which is not really surprising. A potentially interesting group of prospects for a bank are the $25 \%$ that are willing to pay depending on the amount borrowed, as will be explained by the following calculation examples:

TABLE VI

CONSULTING FEE DEPENDING ON THE AMOUNT BORROWED

\begin{tabular}{|l|c|c|c|}
\hline Mortgage loan volume & \multicolumn{3}{|c|}{ Percentage depending on the amount borrowed up to $0.1 \%$} \\
\hline & $0.01 \%$ & $0.05 \%$ & $0.1 \%$ \\
\hline 50,000 & 5 & 25 & 50 \\
\hline 100,000 & 10 & 50 & 100 \\
\hline 250,000 & 25 & 125 & 250 \\
\hline 500,000 & 50 & 250 & 500 \\
\hline $1,000,000$ & 100 & 500 & 1,000 \\
\hline
\end{tabular}


A predominant number of mortgage loans are up to $€ 250,000$ in southern Germany. Thus, in combination with the results of Figure 8 above, a percentage between $0.05 \%$ and $0.1 \%$ can be assumed as optimal for the target group.

As could be derived from question number 1, savings banks and credit union are those that form the majority for offering mortgage loans. Therefore it is interesting, if the willingness to pay of that groups' customers differs a lot from the overall result.

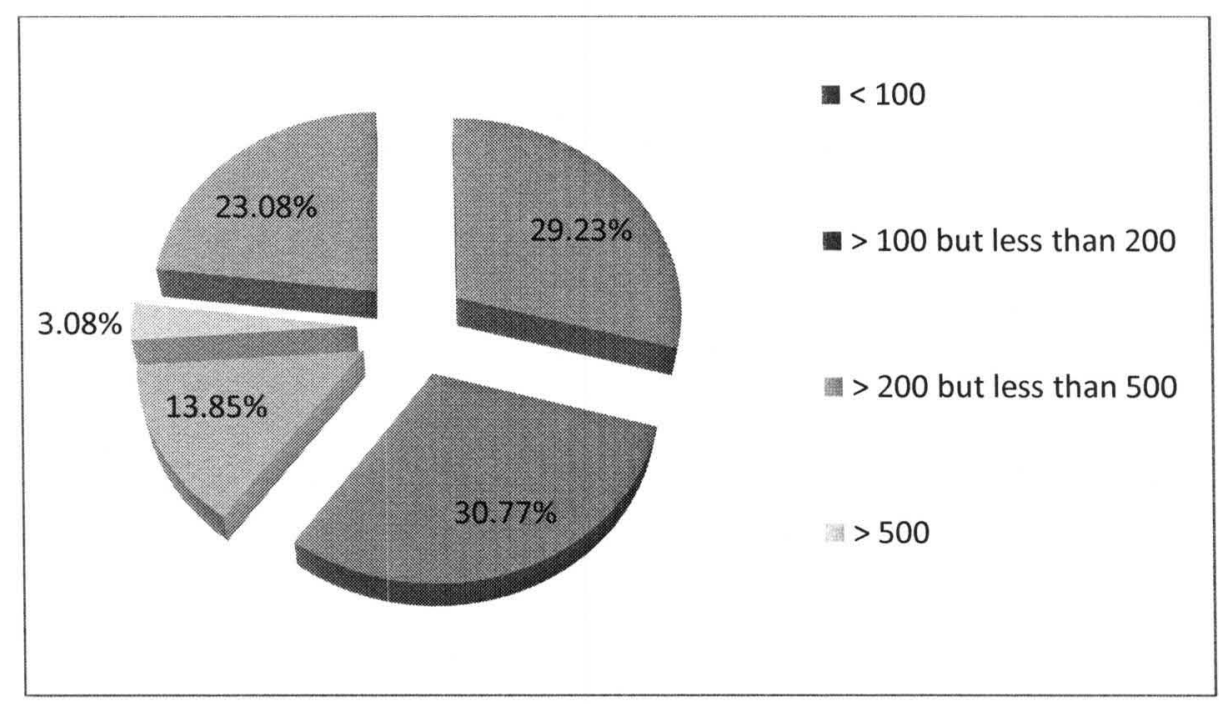

FIGURE 10: Possible Consulting Fees in Savings Banks / Credit Union in contrast to the overall Result

About $5 \%$ more prospects are willing to pay an amount that is higher than $100 €$, but less than $200 €$, and about $3 \%$ more wish to pay depending on the amount borrowed up to $0.1 \%$, as compared to the overall result of Figure 8 .

In addition to that, it is also interesting what prospects of a private bank think about the price range of the mortgage loan consultancy, see Figure 11. 


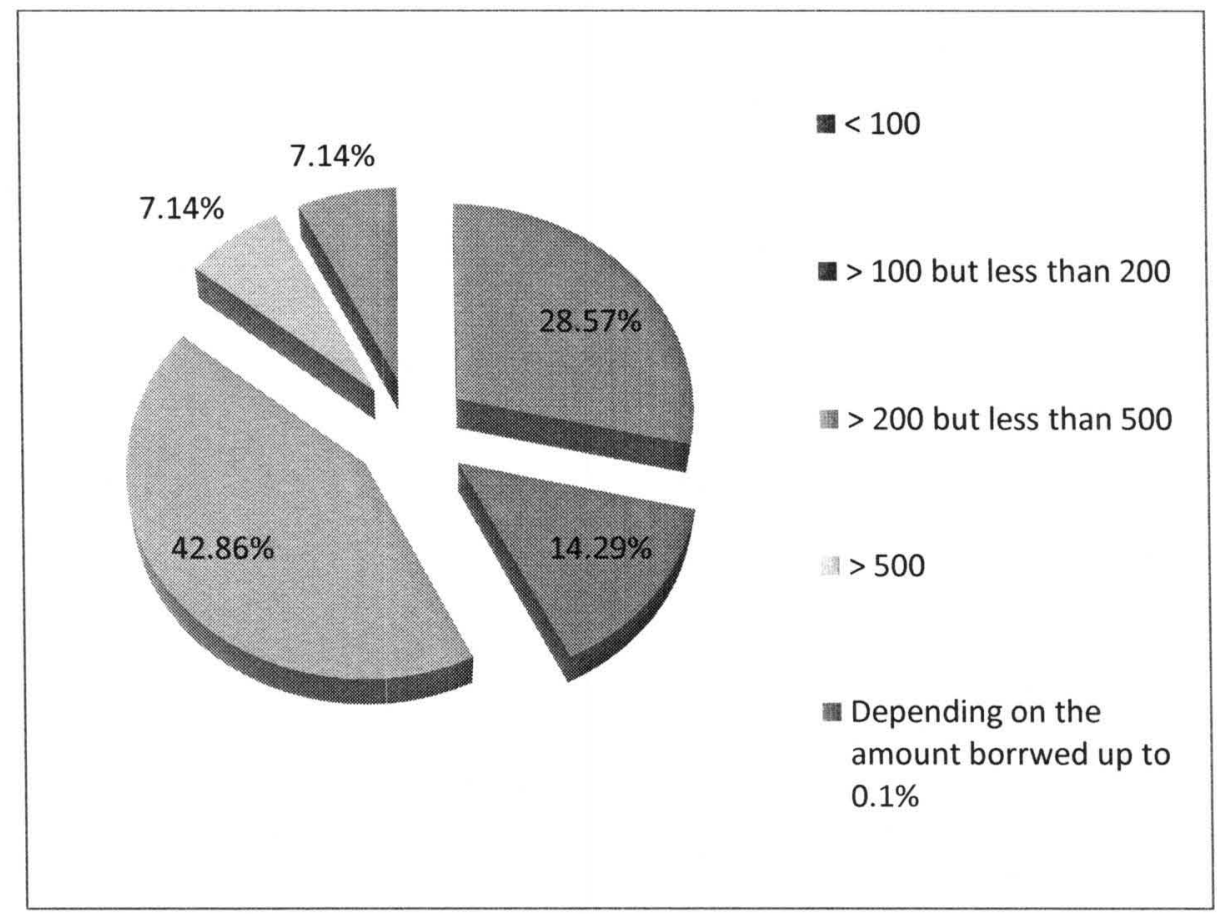

FIGURE 11: Possible Consulting Fees in private Banks in contrast to the overall Result

The graph shows that almost $50 \%$ are willing to pay between $200 €$ and $500 €$, which is comparatively high and could potentially cover the actual costs as estimated on the basis of expert questioning ${ }^{18}$.

The next graph shows the willingness to pay according to the age distribution.

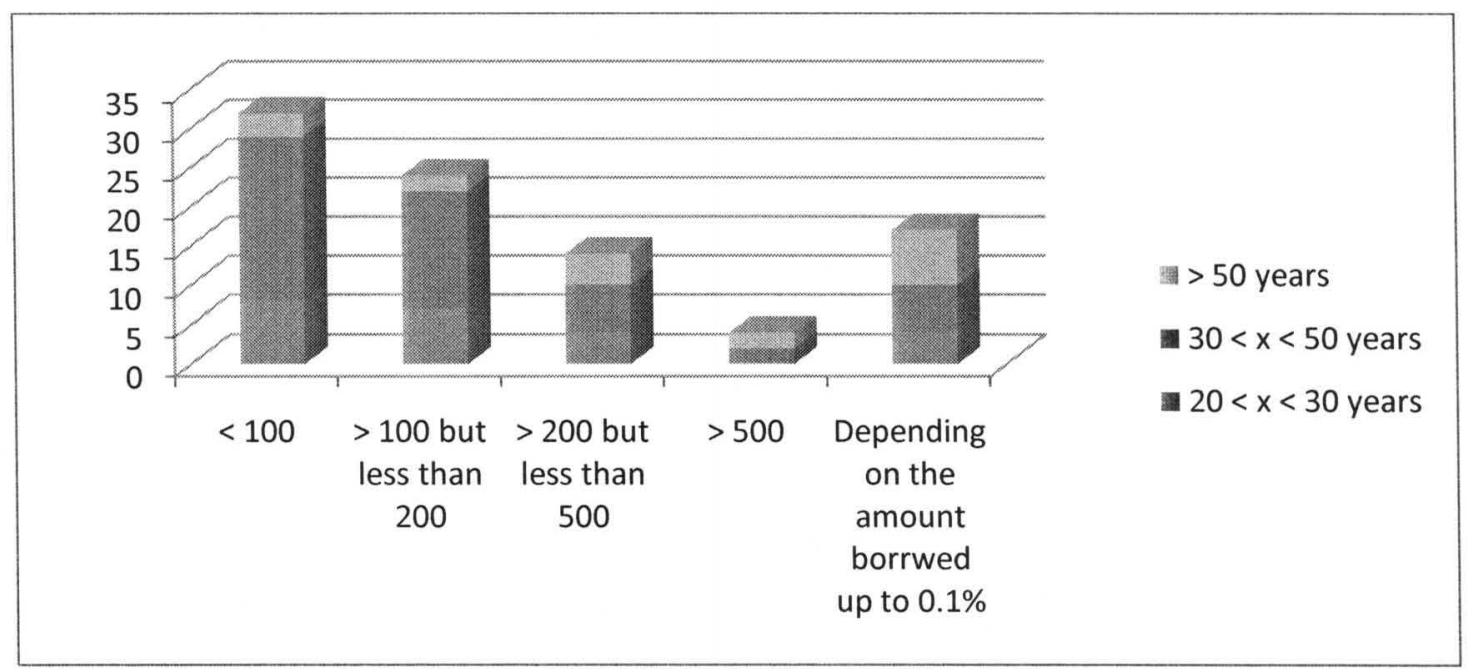

${ }^{18}$ Cf. Table IV 
FIGURE 12: Possible Consulting Fees depending on the Age of the Prospect

As also revealed by numerous other investigations ${ }^{19}$, "older people", i.e. aged 40 and above, are more willing to pay a higher sum for being consulted than younger people, which may at least partly be due to their better economic status and further factors such as marital status ${ }^{20}$.

The second statement is that people aged 50 and above prefer the idea of paying only the sum depending on the amount actually borrowed.

\subsubsection{Question 6: Customer's Bank Preferences}

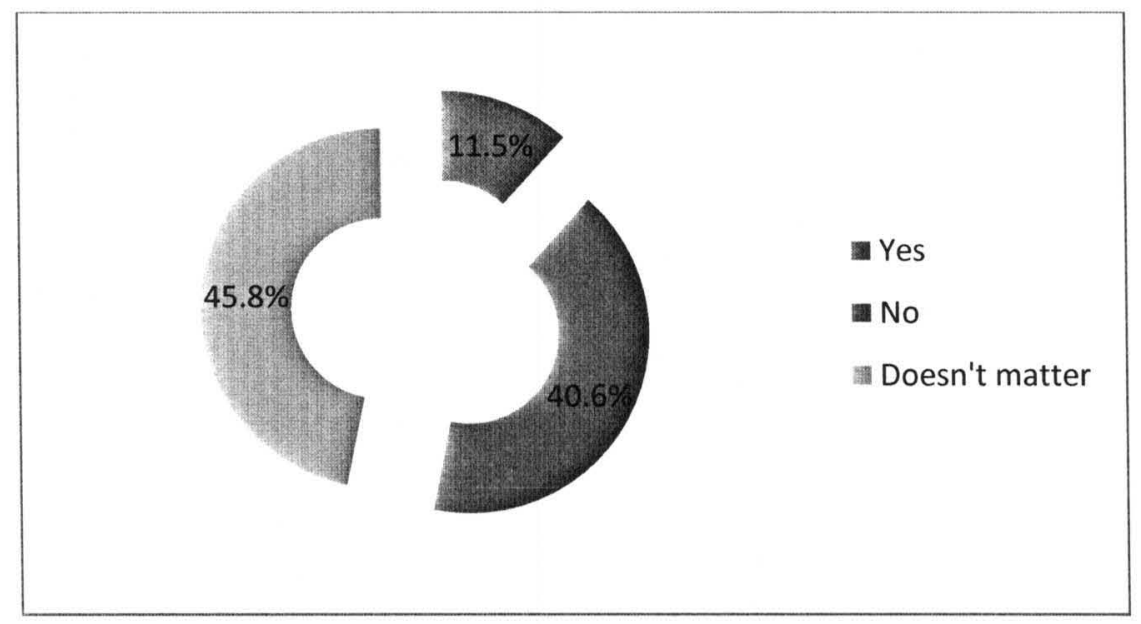

FIGURE 13: Would you rather prefer contracting with a Bank that takes Money for Mortgage Loan Advising?

This is a very interesting result. Though many people are willing to pay money for mortgage loan consultancy ${ }^{21}$, only about $12 \%$ would rather contract with a bank that offers a paid service. This could be interpreted to reflect the fact that prospects do not nec-

${ }^{19}$ Bundesministerium für Wirtschaft und Technologie 2009: Purchasing Power of people aged 60 and above: $317 €$ billion in Germany (2007); consumer share aged 50 and above: $52 \%$ (2005) http://www.wirtschaftsfaktoralter.de/fileadmin/user upload/Infoflyer Wirtschaftsfaktor Alter 01.pdf

${ }^{20} \mathrm{Cf}$. the "DINK" (double income, no kids) effect

${ }^{21} \mathrm{Cf}$. Figure 7 and 8 
essarily link paid services with good consulting quality (yet). In other branches this often is the deciding correlation. The more it costs, the better it is.

\subsubsection{Question 7: Preferred Consultancy Model}

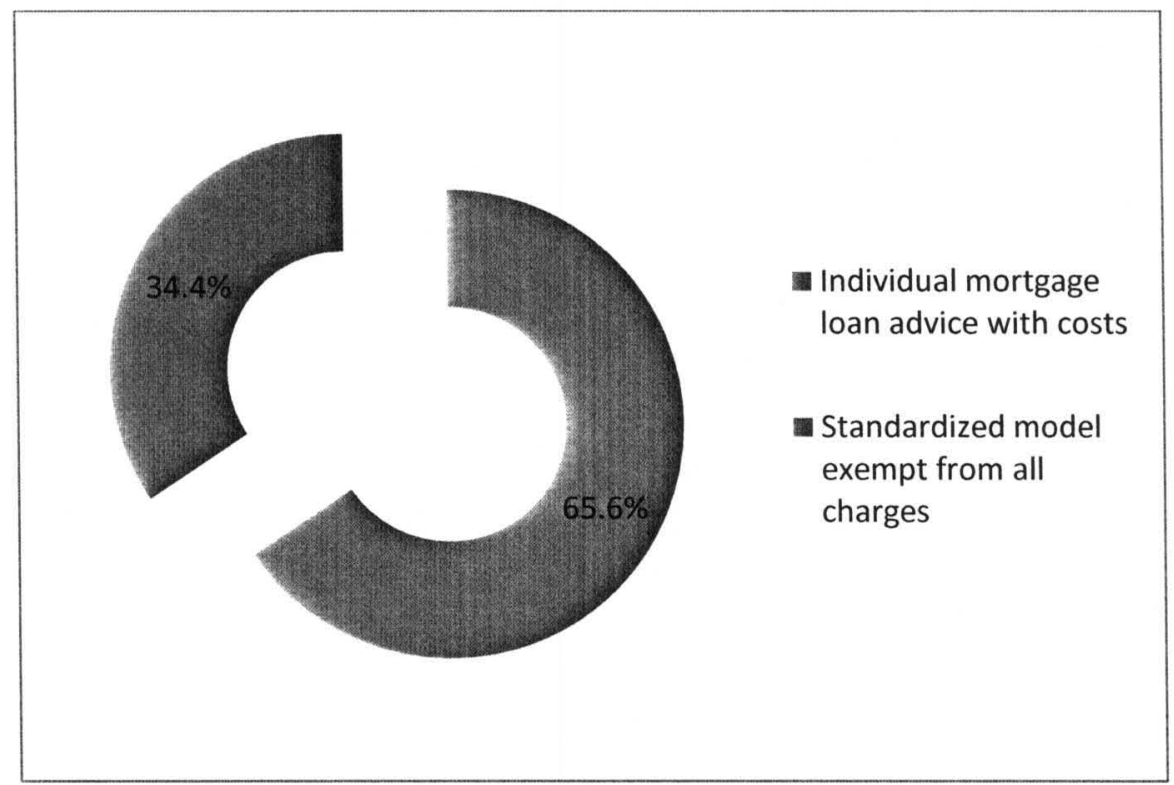

FIGURE 14: Please imagine you could choose between two Types, an Individual Mortgage Loan Advice with Costs and a Standardized Model exempt from any Charges. Which one would you choose?

This graph shows the distribution of the preferred advice model. Almost $2 / 3$ of the interviewees prefer the individual model which is a clear signal to banks to extend and enhance their product range. Not surprisingly, many people that do not want to pay a large amount of money prefer to choose the standard model (see Figure 9). 


\subsubsection{Question 8: Number of Bank Connections}

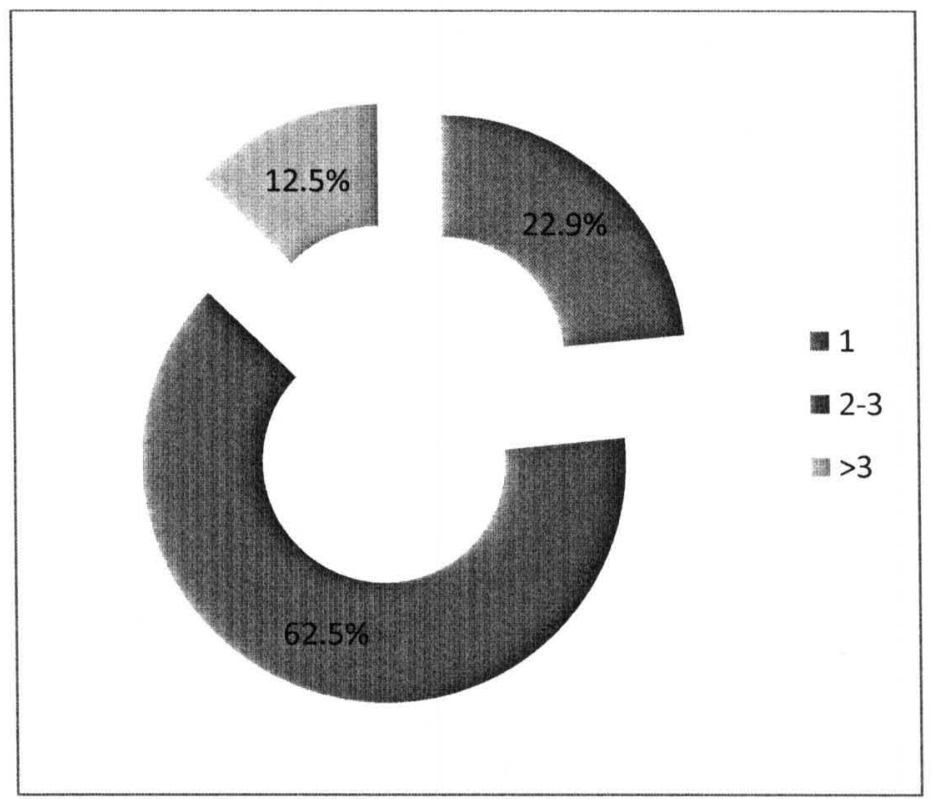

FIGURE 15: Question 8: How many different Bank Connections do you currently have?

Although Germans are really loyal to their main bank, almost $3 / 4$ have two to three different bank connections. But even those that have more than one bank have a very strong binding to their main bank.

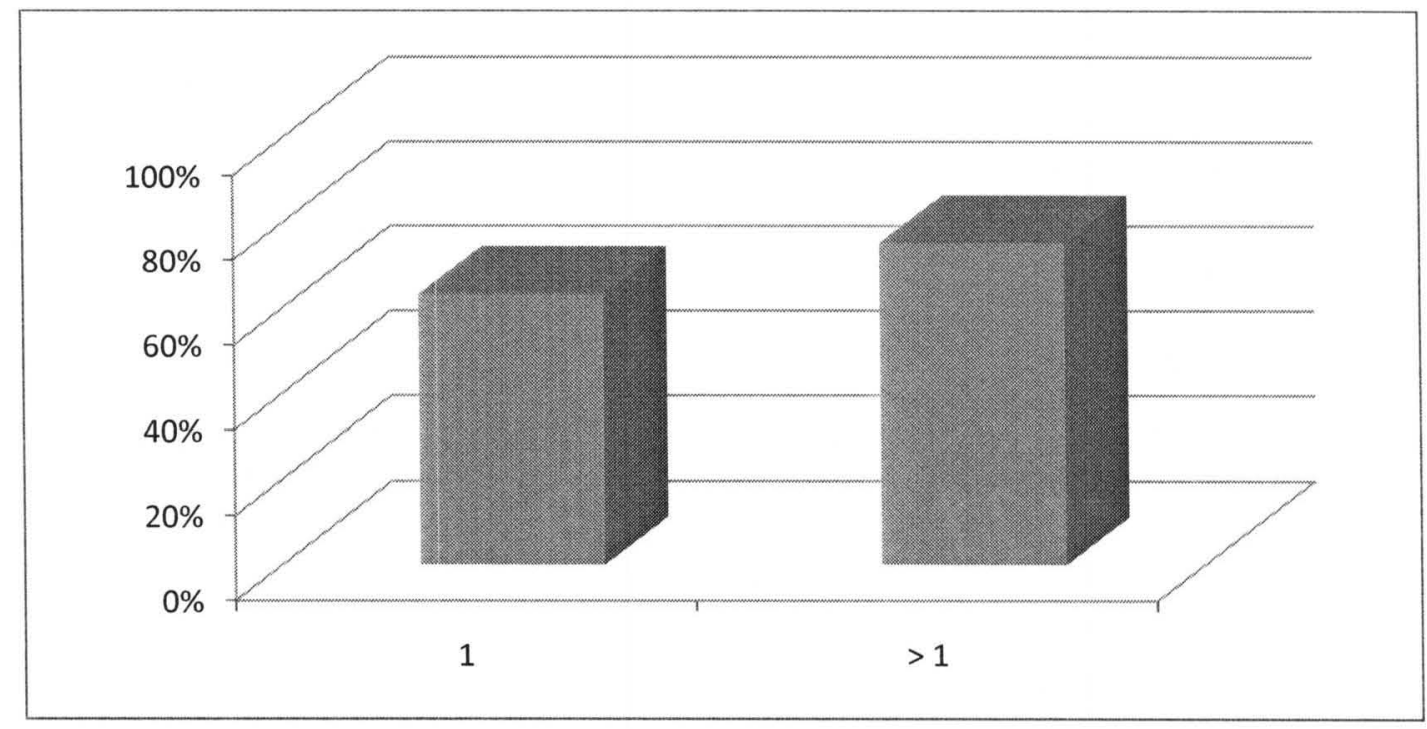

FIGURE 16: Customer loyalty in Correlation to the Number of Bank Connections 
Evidently, this binding is even stronger with those clients that have more than one bank connection (see Figure 17), which is very astonishing. Therefore, this could be the main target group for the banks.

\subsubsection{Question 9: Reasons for different Bank Connections}

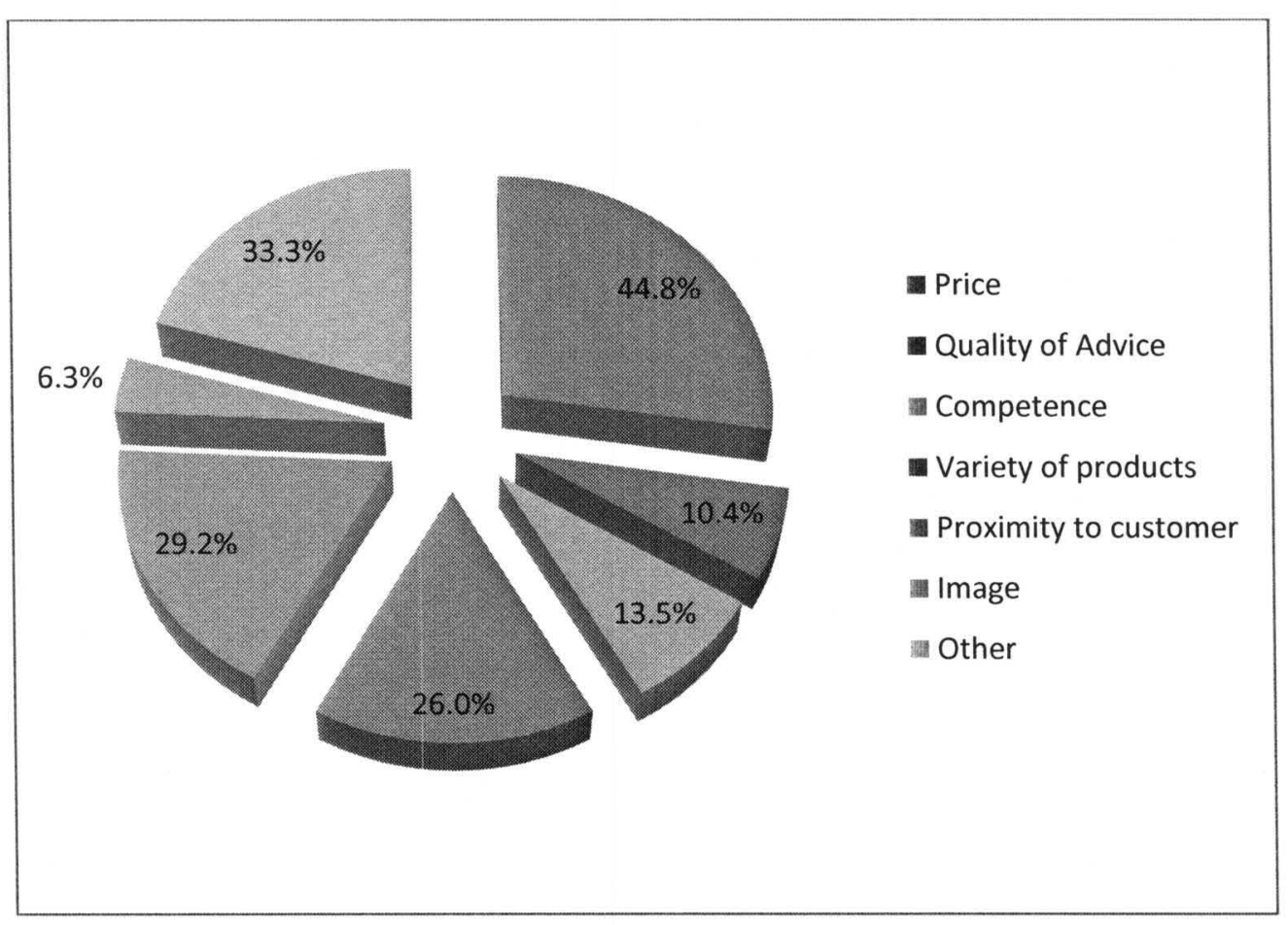

FIGURE 17: What are the Reasons for these different Bank Connections?

This graph shows why customers have different bank connections and can be as well an indicator for banks in which area they should improve as a hint which areas are not that important when not being the main bank.

One of the dominating factors is again price which clearly shows that people want to compare prices in order to get the lowest one. An interesting part of the cake diagram is the "quality of advice" which is relatively low with around $10 \%$ compared to question Number 2 where the "quality of advice" was estimated with around 30\%. This means that people often have these separate bank connections in addition to one bank they rely on 
most. As the author knows, these separate bank connections provide e.g. checking accounts for free or provide very low stock transaction costs. Still, the proximity to the customer is a very important criterion. Especially in times of the ongoing financial crises banks tend to close their affiliates in order to save real estate costs. This is a problem, especially for older, not very mobile, people that depend on the branches and advisors up front.

Another astonishing result was the important role of the "variety of products". As the author didn't expect, prospects like the perspective of many different products in order to compare the advantages and disadvantages of these.

\subsection{Summary}

From the results of the study discussed above, a basic willingness to pay for consulting services in mortgage loan banking can be derived. Most probably, however, customers would not accept consulting fees in a height suitable for covering the actual costs caused by a typical consulting process ${ }^{22}$.

\footnotetext{
${ }^{22}$ Cf. Table IV
} 
3. Monte Carlo Simulation: Effects of Consulting Fees on the Revenue of Mortgage Loan related Business

\subsection{Basics about Monte Carlo Simulation (MC)}

"Simulation is the process of designing a model of a real system and conducting experiments with this model for the purpose either of understanding the behavior of the system or of evaluating various strategies (within the limits imposed by a criterion or set of criteria) for the operation of the system."23

According to Hillig (Hillig, 2005), the term "Monte Carlo Simulation" is an allusion to the coincidental component of gambling in the casinos of Monte Carlo. Moreover, it means that the behavior of the system is probabilistic which means that the model is based on the use of random numbers.

The bases of MC simulation are random experiments that are conducted frequently. According to the results of the MC simulation and probability theory, problems can be solved numerically that cannot be solved analytically, i.e. by evaluating an equation system. To justify this assumption the "law of large numbers" 24 can be consulted. A popular example of an MC Simulation is the approximation of $\pi$ according to Buffon's needle problem.

\subsection{Structure of the Mortgage Loan Revenue Model}

To estimate the revenue a bank can gain in the course of mortgage loan contractions, the below depicted assumptions for the model (see Figure 18) are proposed which consider the principle influences on potential revenue. The model is based on a basic profit equation which enables to determine the revenue depending on several parameters

\footnotetext{
${ }^{23}$ Shannon, R.E. (1975), page 2

${ }^{24}$ The relative frequency of a random result approaches the probability of this random experiment if this random experiment is conducted frequently.
} 
such as a number of contracts, variable costs depending on the contracting process and fixed costs. More specifically, the model comprises two contributions to revenue, the first of which reflects what may be considered the standard portion of revenue in mortgage loan banking, namely the margin. The second contribution defines possible effect of consulting fees on the revenue. In analogy to the basic profit equation, fixed costs and variable costs are deducted from the aforementioned contributions to the revenue term.

To determine the first contribution to revenue, the model considers a consulting agent of a bank who conducts a certain number of consulting sessions per year. The actual number of mortgage loan contractions - as a consequence of said consulting sessions - is derived from the number of consulting sessions by means of the contracting rate, the value range of which has been chosen on the basis of expert questioning in the field of mortgage loan consulting. I.e., as illustrated by Figure 18, the consulting agent's consulting process is modeled by a first random parameter (number of consulting sessions) and by said contracting rate, which is also a random parameter.

The margin-based contribution to revenue is finally evaluated by multiplying the contracting rate with the number of consulting sessions, which yields the number of contracts per year. The number of contracts per year is transformed to actual revenue by multiplication with a fictitious amount borrowed and the margin, both of which are also considered by the present model in the form of random parameters.

The second contribution to revenue is constituted by the consulting fees, which according to the model - are only debited in the case of non-contracting and are assumed to be constant, i.e. non-random. The consulting fee-based profit component - in contrast 
to the margin-based profit-component - only contributes to estimated revenue in such cases, where a consulting session has taken place but has not led to a contract.

As will be explained in detail in chapter 3.3 below, the depicted model has been evaluated for various scenarios being characterized by different values for the consulting fees ranging from $0 €, 100 €, 200 €, 300 €$ to $500 €$. The case of $0 €$ consulting fees obviously reflects the current situation. 


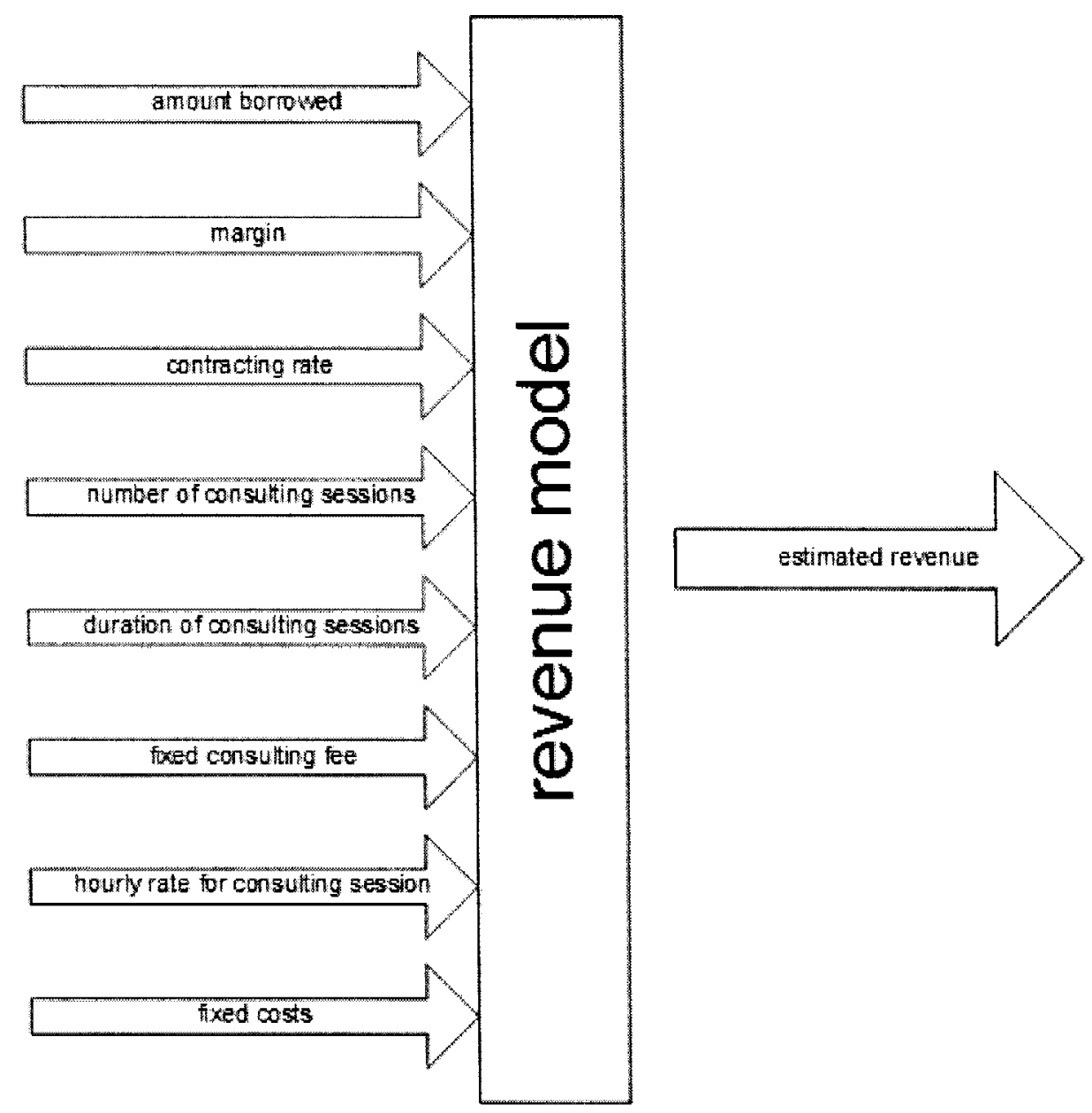

legend:

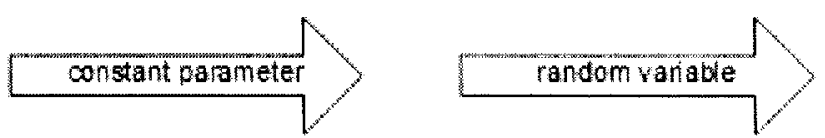

FIGURE 18: Assumptions for the Model 


\subsubsection{Assumptions for Input Data}

TABLE VII

RANDOM VARIABLES OF THE MODEL

\begin{tabular}{|l|l|l|l|l|}
\hline Input Data & $\begin{array}{l}\text { Formula } \\
\text { Symbol }\end{array}$ & $\begin{array}{l}\text { Type of distribu- } \\
\text { tion }\end{array}$ & $\begin{array}{l}\text { Mean } \\
\text { value }\end{array}$ & $\begin{array}{l}\text { Standard } \\
\text { deviation }\end{array}$ \\
\hline Amount borrowed & AB & Normally & $150,000 €$ & $50,000 €$ \\
\hline Margin & $\mathrm{M}$ & $\begin{array}{l}\text { Specially generat- } \\
\text { ed }{ }^{25} \text { based on } \\
\text { expert knowledge }\end{array}$ & $\sim 1.2 \%$ & \\
\hline $\begin{array}{l}\text { Number of consult- } \\
\text { ing sessions }\end{array}$ & $\mathrm{N}$ & Normally & 180 & 20 \\
\hline $\begin{array}{l}\text { Duration of consult- } \\
\text { ing sessions }\end{array}$ & $\mathrm{D}$ & Normally & $3 \mathrm{~h}$ & $1 \mathrm{~h}$ \\
\hline Contracting Rate & $\mathrm{P}$ & Normally & $35 \%$ & $5 \%$ \\
\hline
\end{tabular}

TABLE VIII

FIXED VARIABLES OF THE MODEL

\begin{tabular}{|l|l|l|}
\hline Input Data & Formula Symbol & Value \\
\hline Fixed consulting fee & F & $0 ; 100 €-500 €$ \\
\hline $\begin{array}{l}\text { Hourly rate for consulting session } \\
\text { according to Table III }\end{array}$ & $\mathrm{R}$ & $40.18 €$ \\
\hline Fixed costs according to Table III & FC & $52,000 €$ \\
\hline
\end{tabular}

${ }^{25}$ Cf. chapter 3.2.3 
The model is thus based on the following formula:

Estimated Revenue $=N * P * A B * M+N *(1-P) * F-(N * D * R+F C)$

- Equation 1 -

\subsubsection{Amount Borrowed}

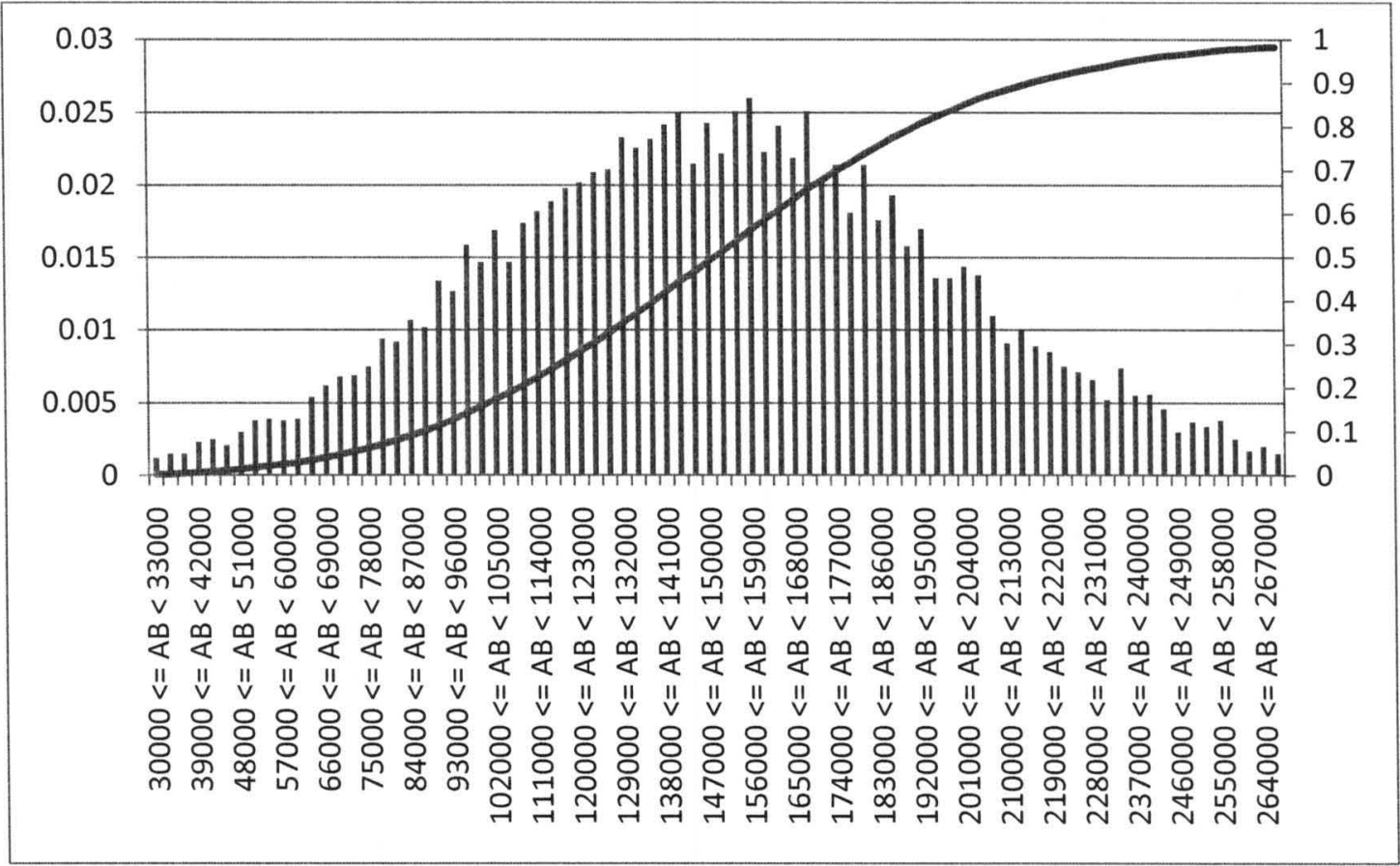

FIGURE 19: Histogram of the "Amount borrowed"

The amount borrowed is used in the present model as the basis for determining the margin-related revenue component of the estimated total revenue. A normal distribution is assumed to properly reflect actual numbers. According to the author's knowledge, the mean amount borrowed per person for a mortgage loan in southern Germany is around $150,000 €$. For the evaluation of the model, the standard deviation is assumed to be $50,000 €$ 


\subsubsection{Margin}

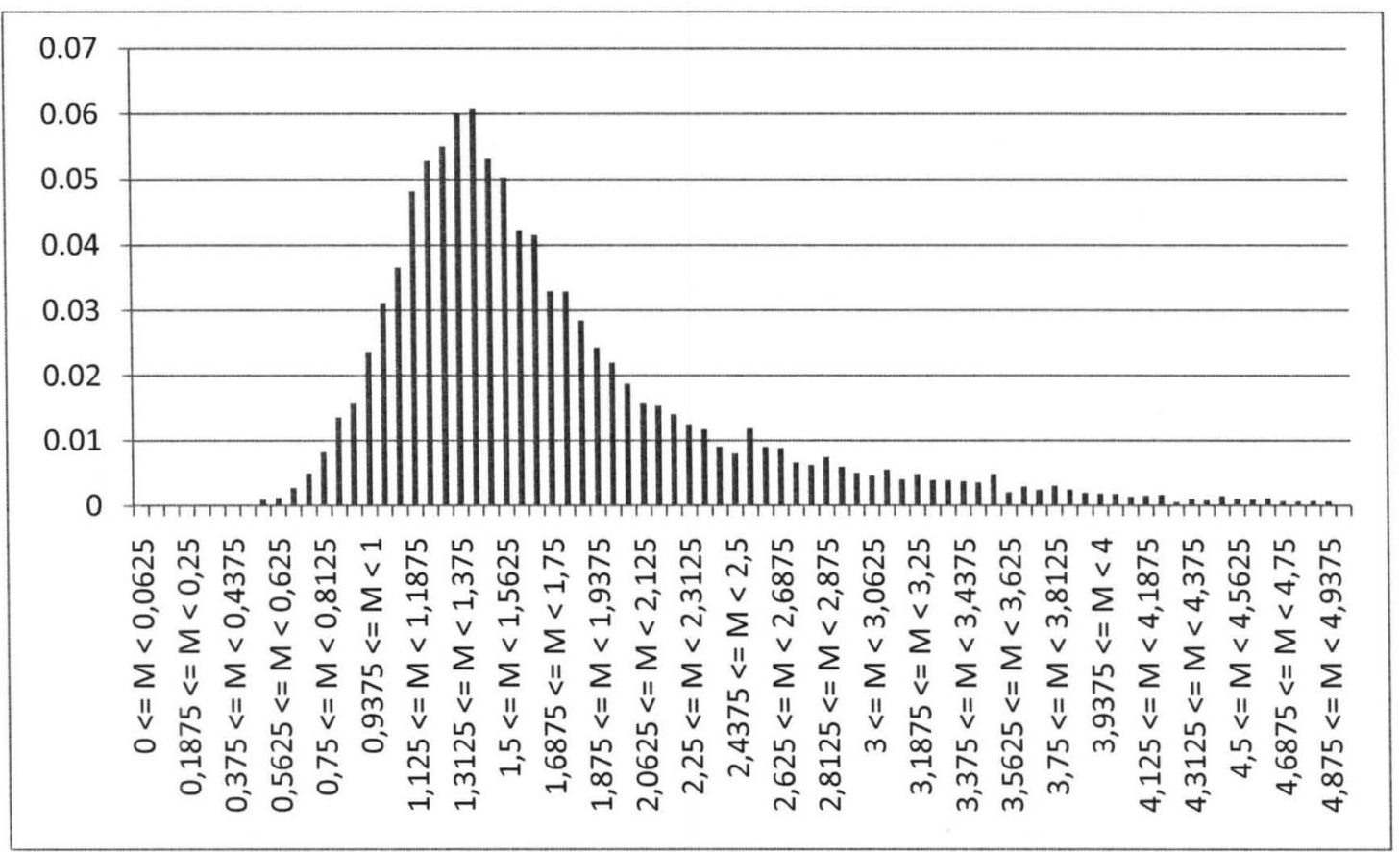

FIGURE 20: Histogram of the "Margin"

The "Margin" was more complicated to simulate than other random variables of the model, where a straightforward normal distribution could be employed. This is due to the fact that there are a lot more customers with a bad credit rating than those with good ones. As was explicated before, the credit margin in Germany is based on the POD which is basically the credit rating. Thus, to properly reflect the real situation in southern Germany, the Margin must have a lot of values higher than $1.2 \%$ but only a small number of values below $1.2 \%$ and rather none of them below $0.4 \%{ }^{26}$.

The mean value is situated around $1.2 \%$. The special distribution shown above was generated by overlaying several distributions with different mean values and standard deviations to generate a graph that represents reality approximatively. To account for a

\footnotetext{
${ }^{26}$ For margins below $0.4 \%$, the bank wouldn't make any money because the fixed costs were not covered at all. Margins around $0.4 \%$ are only reserved for $A+$ (exceptionally good) credit ratings.
} 
majority of margin values exceeding $1.2 \%$, a squared normal distribution was added with a weighting factor that has been obtained by experiment.

\subsubsection{Number of Consulting Sessions}

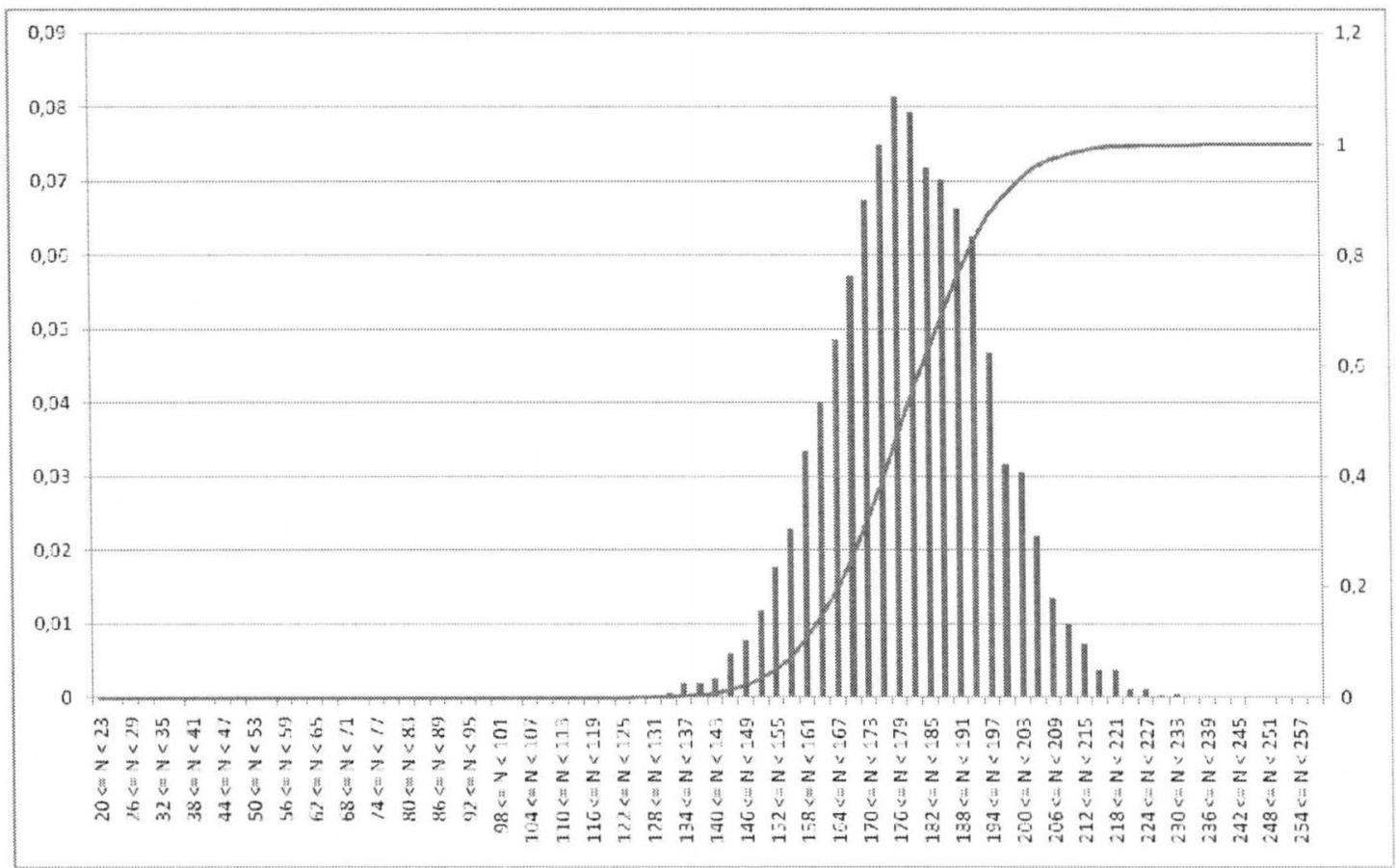

FIGURE 21: Histogram of the "Number of consulting sessions" per Year per Advisor

As already defined by Table VII, a normal distribution was found to properly reflect the current consulting sessions situation. The distribution of the Number of Consulting sessions was designed with a mean value of 180 sessions and a standard deviation of 15 sessions, which has been verified by expert questioning. This value is based on a realistic approach for a bank advisor specialized in the field of mortgage loan consultancy with only some minor tasks in asset allocation and payment transactions consultancy. 


\subsubsection{Duration of Consulting Session}

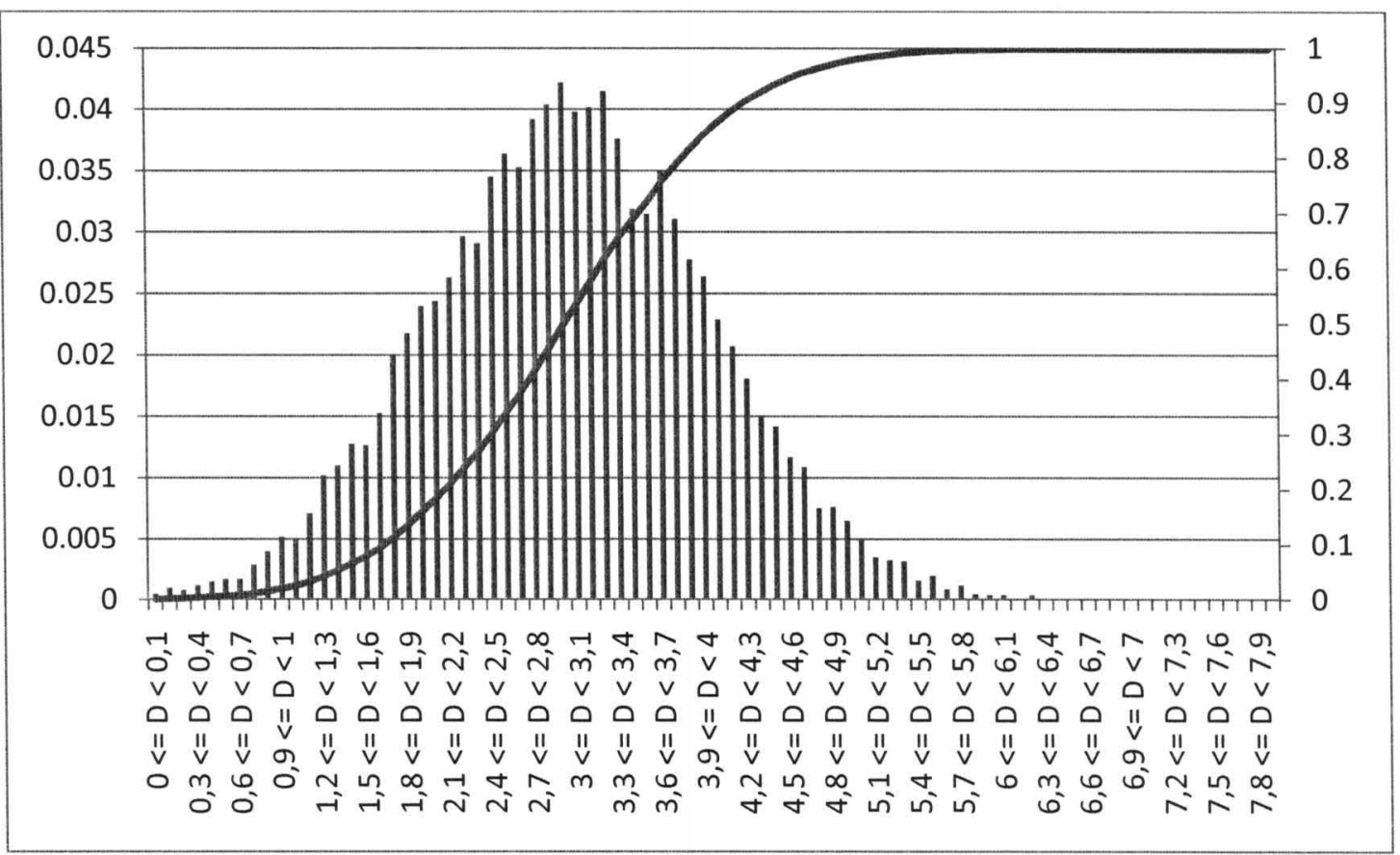

FIGURE 22: Histogram of the "Duration of Consulting Session"

This value is used to determine variable costs involved in the consulting process. According to the author's own experience, a profound mortgage loan consultancy takes around 3 hours. Therefore, the mean value was set to three hours, the standard deviation to 1 hour. This value is about $25 \%$ lower than the example calculated in Chapter 2.5. The difference is that Chapter 2.5 reflects on an extensive advice (worst case), whereas this example focuses on a standard mortgage loan advice. An extensive mortgage loan advice can take up to 6 hours which is also represented in the graph above but which does not reflect the standard situation. 


\subsubsection{Contracting Rate}

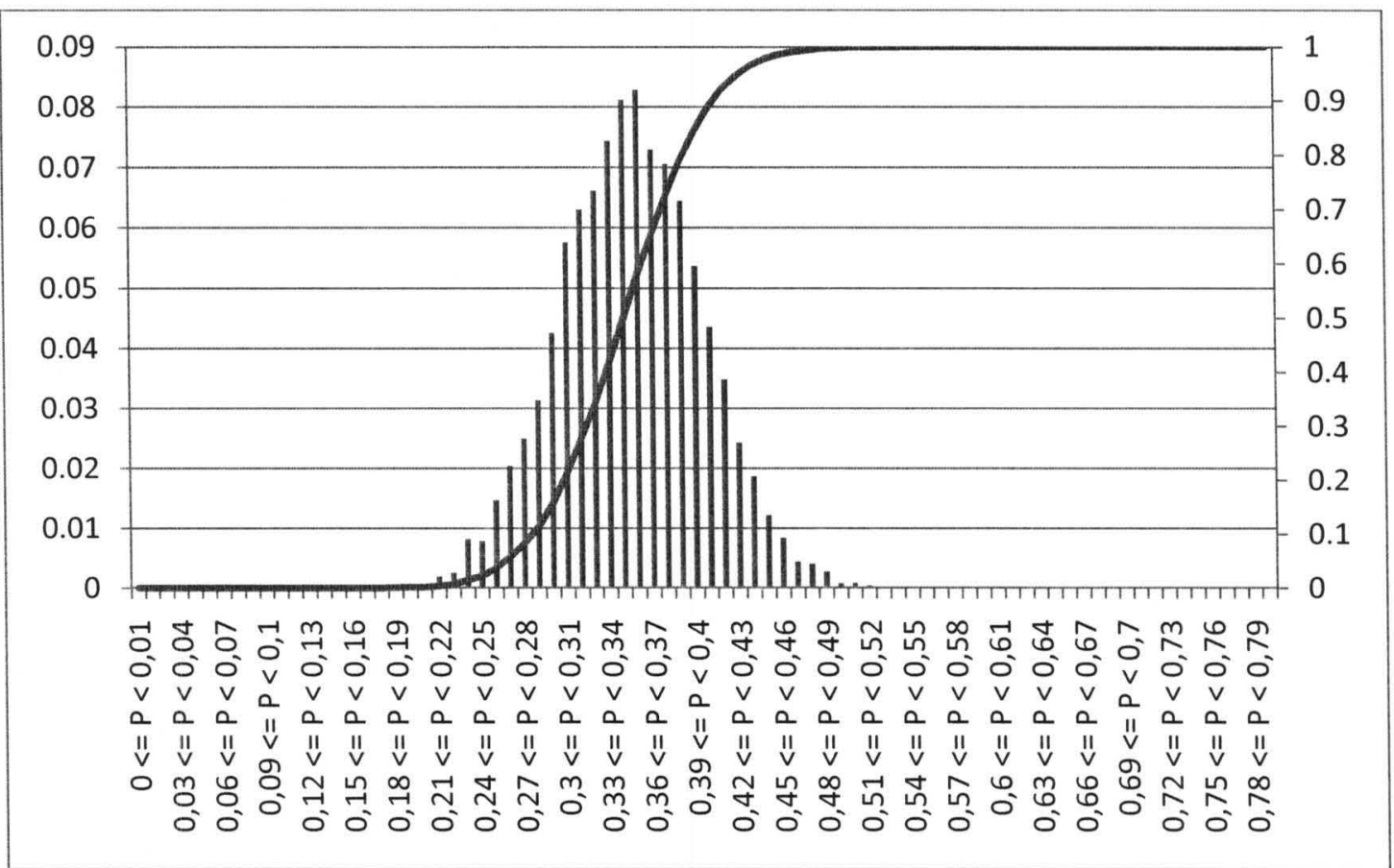

\section{FIGURE 23: Histogram of the "Contracting Rate"}

The above shown histogram of the normally distributed contracting rate has a mean value of $35 \%$ and a standard deviation of $5 \%$. The comparatively low contracting rate is due to the fact that Germans like to compare prices and services. Almost everybody invites more than one offer before deciding upon a precise offer. Most people even invite 3 or more offers. Thus, it was assumed that the real contracting rate is around $35 \%$, the rest are only offers to compare. In this context it is obvious how important it is to introduce consulting fees because most offers do not lead to a contract. 


\subsection{Evaluation of the Model}

Equation 1 has been evaluated 10,000 times based on the above explained random variables and fixed parameters to obtain the simulation results explained in the following chapters.

\subsubsection{Estimated Revenue - Present Situation}

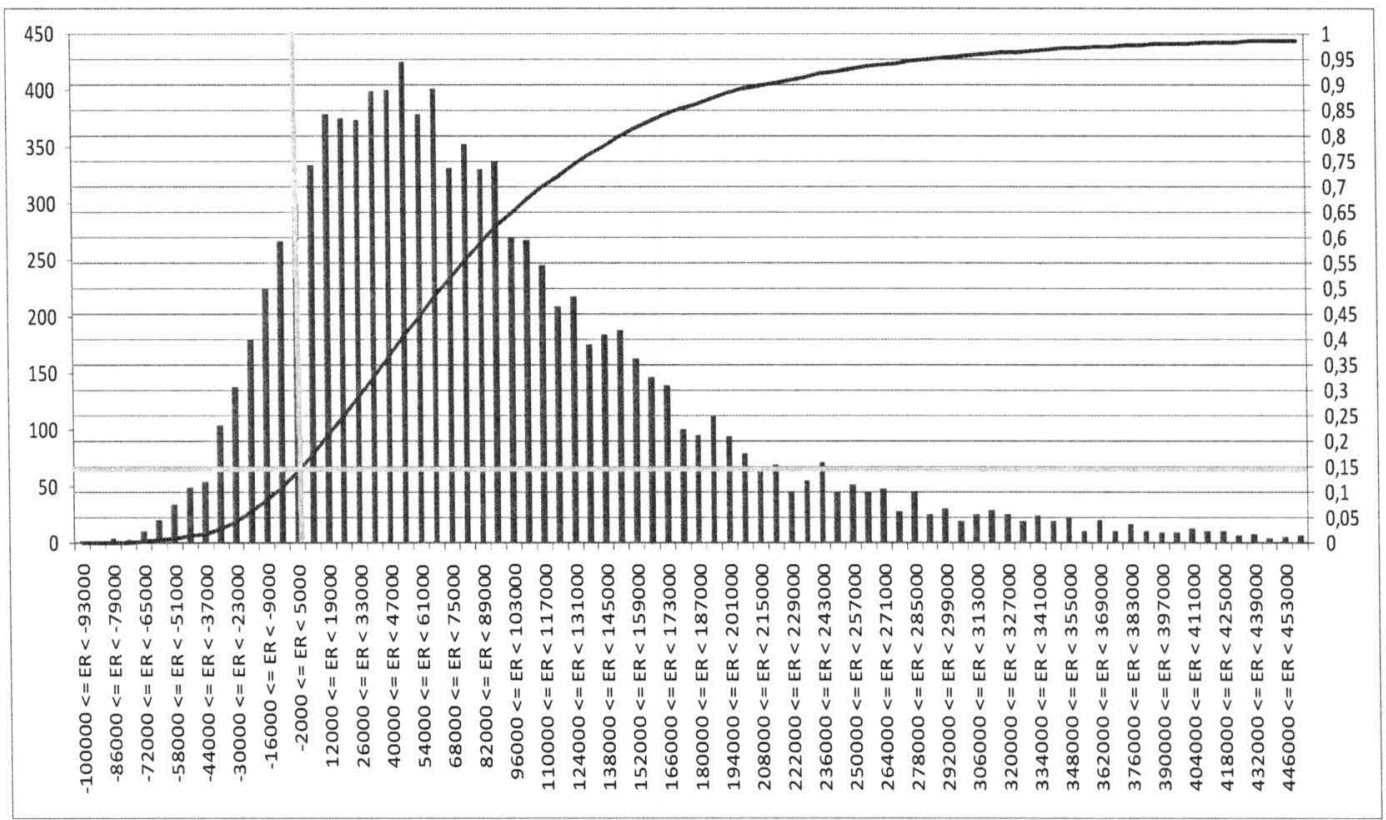

FIGURE 24: Estimated Revenue based on Consulting Fee " $0 €$ ”' (present state)

Figure 24 shows the present situation of the estimated revenue of mortgage loan consultancy. As the graph shows, statistically roughly $15 \%$ of given consultancies are not profitable for the bank, because they yield a non-positive estimated revenue, which is on the one hand due to low margins ${ }^{27}$ and / or a low amount borrowed, and on the other hand due to a high probability of non-contractions though having the fixed costs of the consult-

\footnotetext{
${ }^{27}$ Which does for example not represent an adequate risk of the credit
} 
ing agent. More precisely, a detailed evaluation of the data basis for Figure 24 yielded a rate of $12 \%$ of unsuccessful, i.e. non-lucrative consulting sessions ${ }^{28}$.

The following simulated estimated revenues will demonstrate the effect of a consulting fee on the profitability of the bank regarding mortgage loan consultancy.

\subsubsection{Estimated Revenue $-100 €$ Consulting Fee}

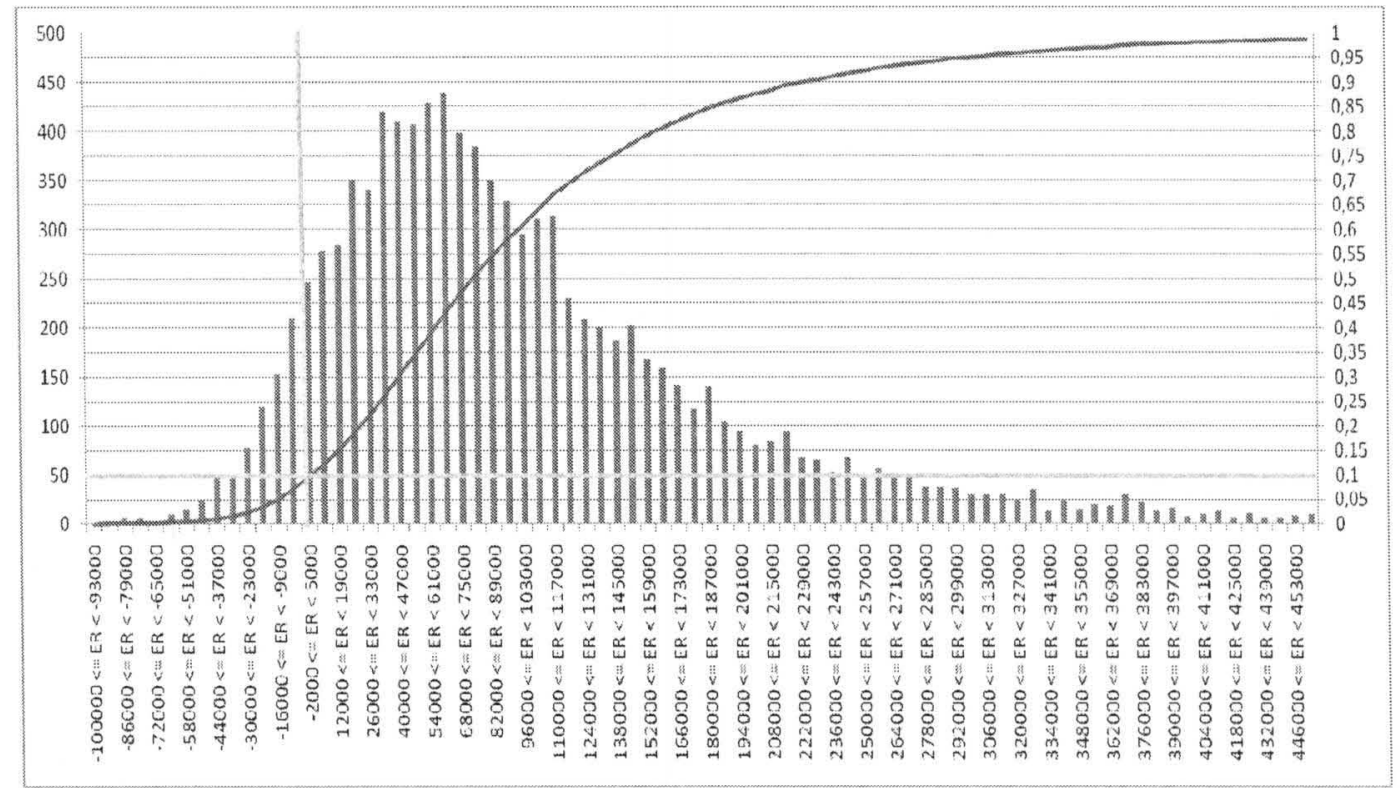

FIGURE 25: Estimated Revenue based on Consulting Fee "100 €”

As calculated anew (see Figure 25), now, only $7.3 \%$ of the consultancies are not profitable for the bank, which gets obvious by considering Equation 1:

$$
\text { Estimated Revenue }=N * P * A B * M+(N * D * R+F C)
$$

Most terms of the formula do not change compared to the standard case, but the green part of the formula does. In the standard case, this green term results in " 0 " due to the vanishing consulting fees $(F=0)$. Now, by means of the non-vanishing consulting fees, the bank generates extra money even if people fail to contract with the bank. Thus, the sum of the total estimated revenue increases.

\footnotetext{
${ }^{28}$ Also cf. Table IX
} 
On a first glance, the overall improvement (only about $4.7 \%$ ) of the estimated total revenue generated by the consultancy fee $(100 €)$ seems to be relatively small. This impression, however, is deceiving, because in fact, the bank lowered the risk of unprofitable mortgage loan banking contracts for about $40 \%$ by introducing a comparatively low consulting fee.

\subsubsection{Estimated Revenue $-200 €$ Consulting Fee}

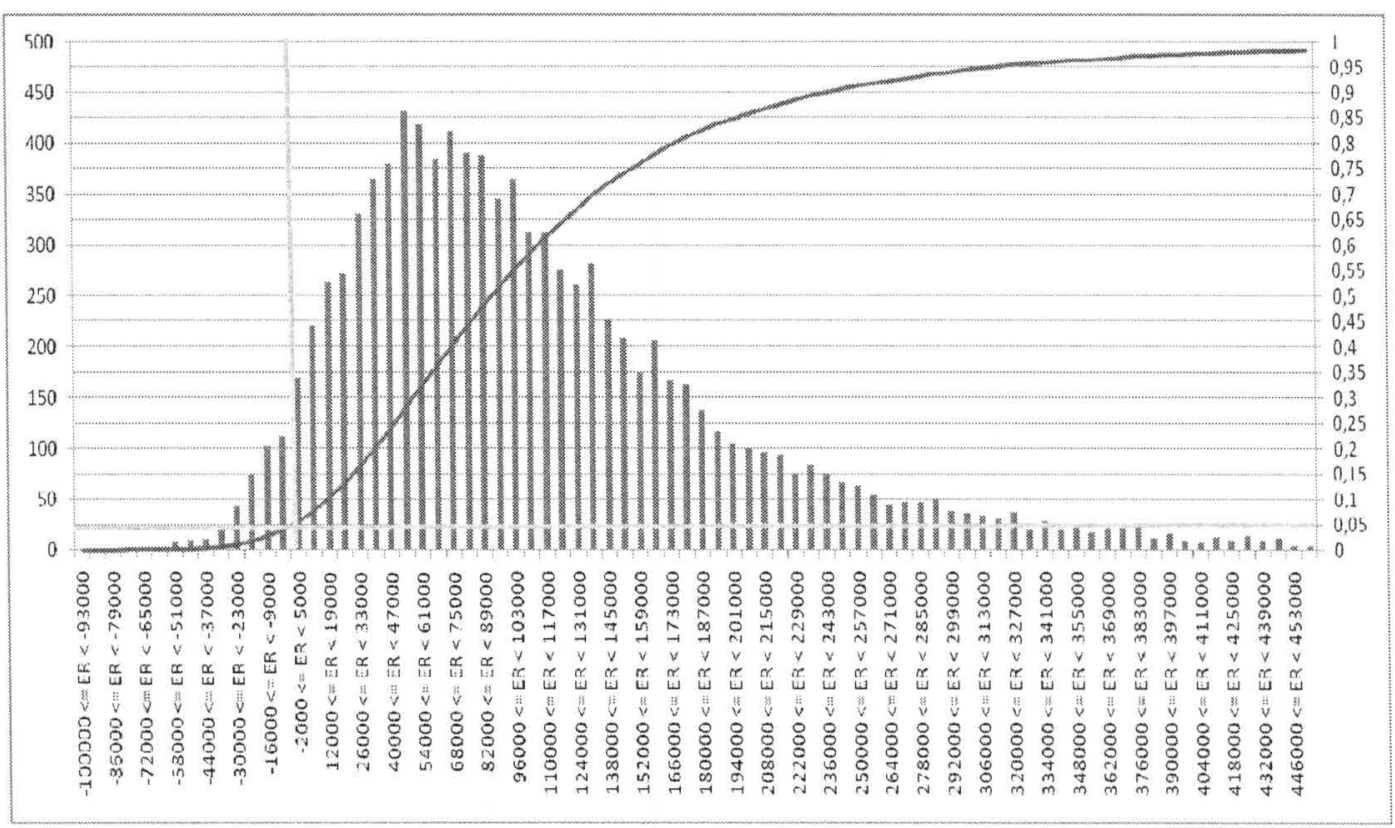

FIGURE 26: Estimated Revenue based on Consulting Fee "200 €”

Given again Equation 1, the green term, compared to FIGURE 26, gets bigger depending on the consulting fee.

$$
\text { Estimated Revenue }=N * P * A B * M+\quad-(N * D * R+F C)
$$

In the present case, the risk of unprofitable mortgage loan banking is only about $3.9 \%$, which means a reduction of $67 \%$ of the risk for the bank in comparison to the standard version without $0 €$ consulting fees. 


\subsubsection{Estimated Revenue $-300 €$ Consulting Fee}

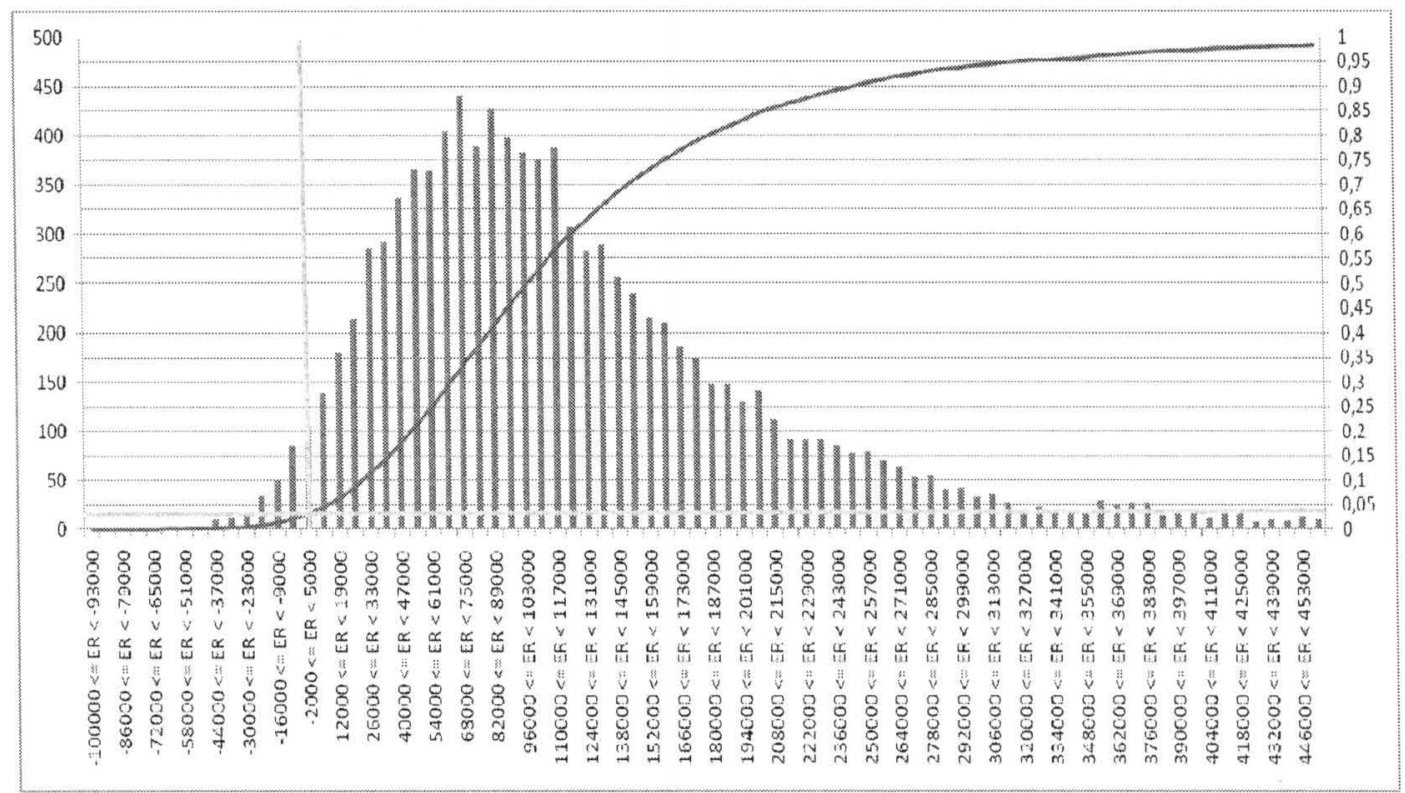

FIGURE 27: Estimated Revenue based on Consulting Fee "300 €”

In this case, the risk of unprofitable mortgage loan banking is only about $2.4 \%$, which means a reduction of $80 \%$ of the risk for the bank in comparison to the standard version without consulting fees. 


\subsubsection{Estimated Revenue $-500 €$ Consulting Fee}

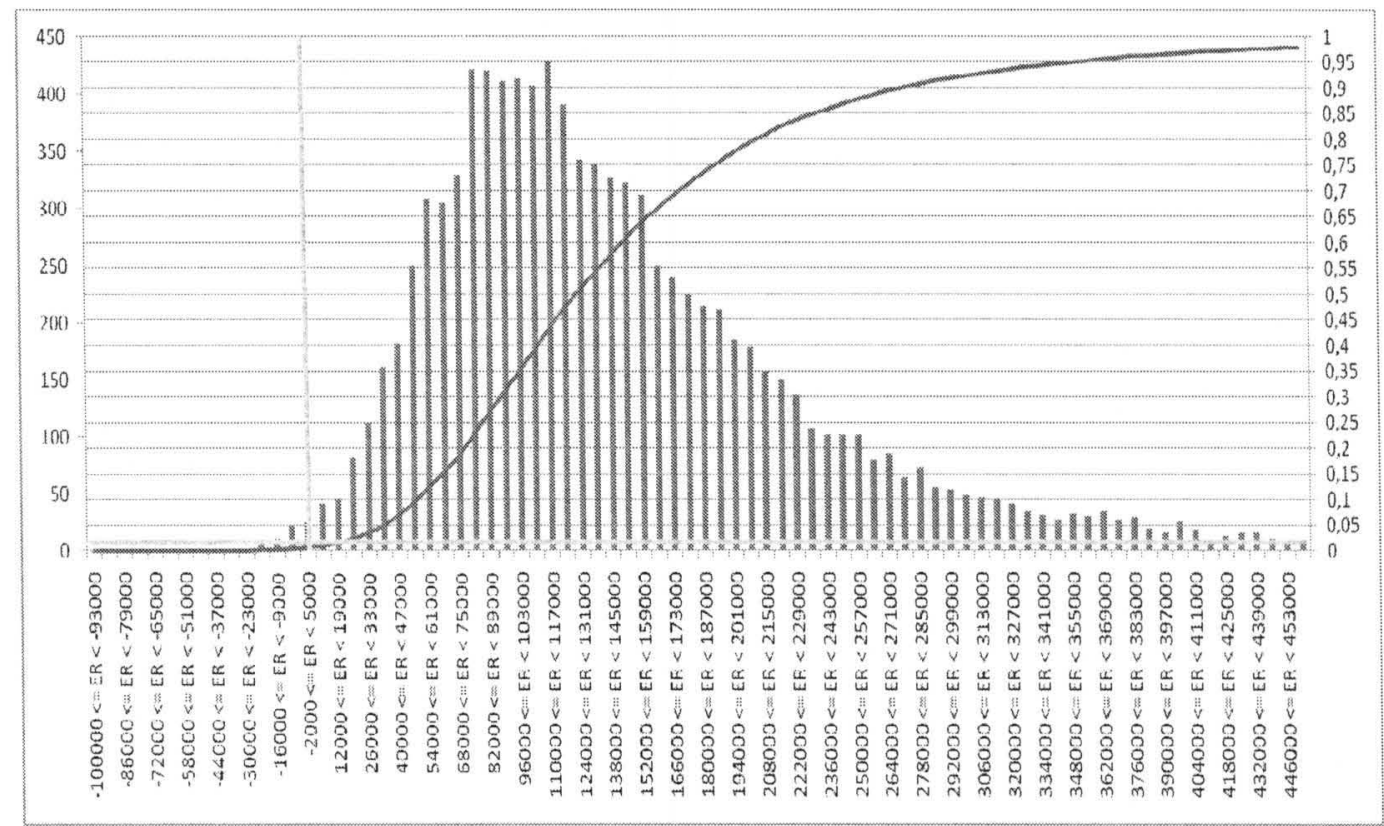

FIGURE 28: Estimated Revenue based on Consulting Fee "500 €”

If one considers the $500 €$ case (see Figure 28), it is obvious that the bank's risk to generate unprofitable mortgage loan consultancies almost faded to zero (exactly: $0.5 \%$ ).

Unfortunately, this scenario will be hard to establish in German banking industry, because only very few prospects are willing to pay such a huge amount of money as could be derived from the results of the study in Chapter 2 . 


\subsection{Discussion of Results and Prospects}

\subsubsection{Estimated Revenue - Summary Remarks}

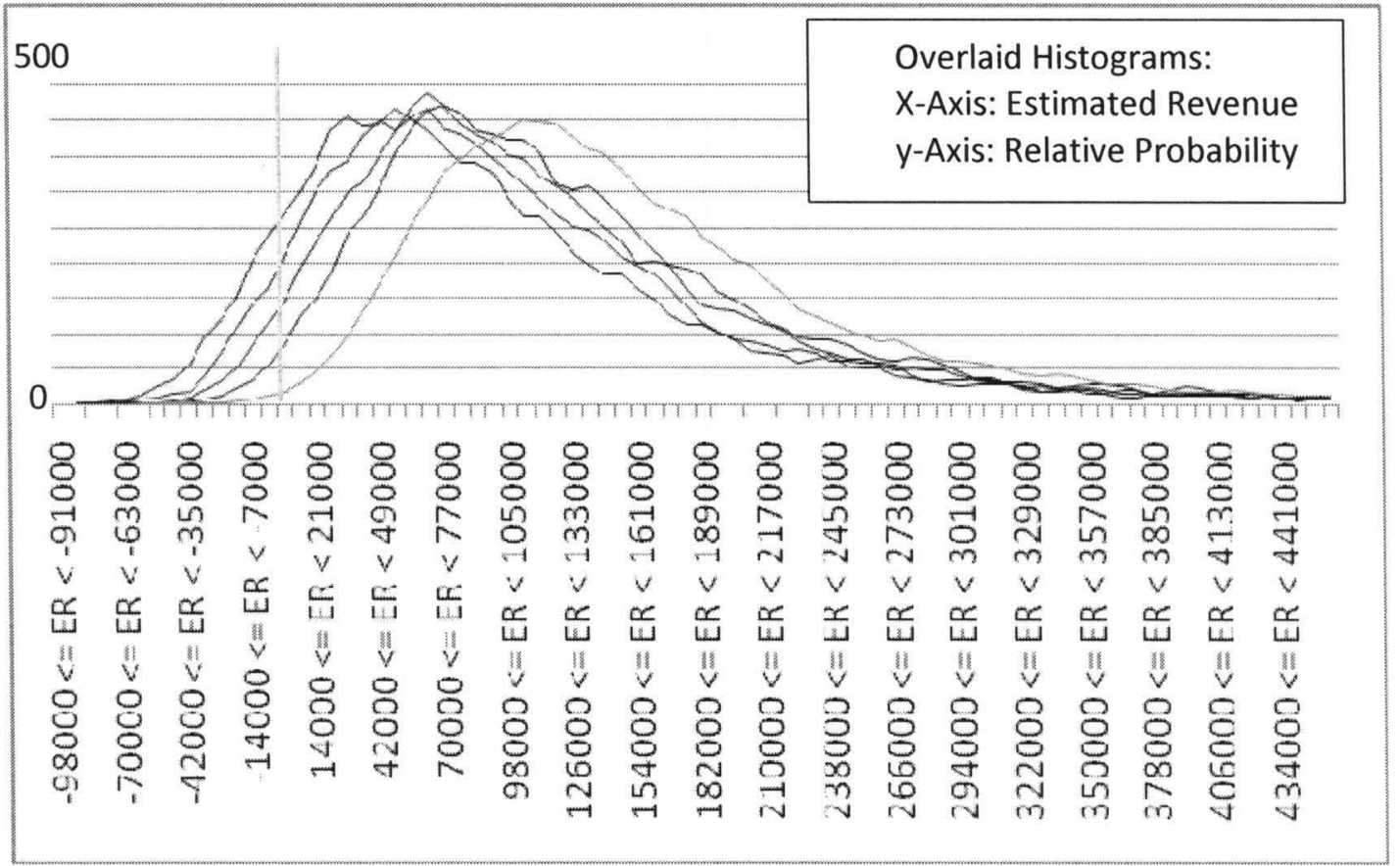

FIGURE 29: Estimated Revenue based on Consulting Fee - Overview

Figure 29 above depicts smoothed histograms for estimated revenue for a comparison of different values for the consultancy fees. It is obvious that the effect of the consultancy fee is the most important when considering low total revenues. The higher the overall revenue, the effect of a fixed consultancy fee gets less important. These cases are dominated by huge values of amounts borrowed and / or huge margins (because of the high POD). In these cases, it is not necessary to charge the consulting fee at all. 


\subsubsection{Risk Reduction Matrix of unprofitable Consulting Sessions}

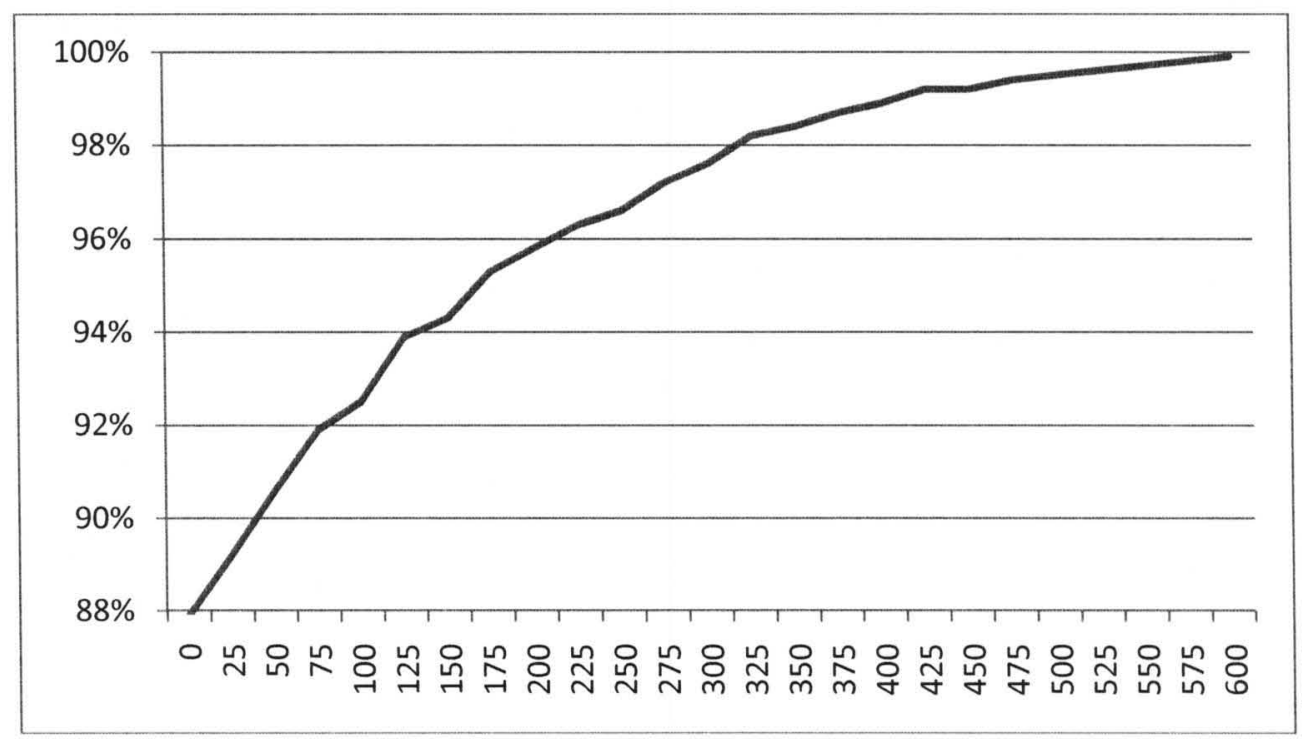

FIGURE 30: Probability of profitable mortgage loan consulting sessions

Figure 30 depicts the probability of profitable mortgage loan consulting sessions, i.e. estimated revenue $\mathrm{ER}>=0$, over the consulting fee in $€$. Apart from the samples already discussed above (situation for $F=0 €, 100 €, 200 €, 300 €, 500 €$ ), intermediate values can also be gathered from this graph. Apparently, the slope is steepest for low consulting fees, i.e. substantial effects on estimated revenue (ER) can already be achieved by introducing comparatively low consulting fees. Moreover, evidently, the most significant improvement of ER is achieved by providing non-vanishing consulting fees at all.

Table IX depicts an overview on the enlargement of profitability by increasing consulting fees. The "best" risk reduction cases are highlighted in green. 
TABLE IX

RISK REDUCTION MATRIX

\begin{tabular}{|c|c|c|c|}
\hline $\begin{array}{c}\text { Consulting fee } \\
\text { in } €\end{array}$ & Statistical profitability & $\begin{array}{c}\text { Enlargement by } \\
\text { increased consulting fee }\end{array}$ & $\begin{array}{c}\text { Risk } \\
\text { Reduction }\end{array}$ \\
\hline 0 & $88 \%$ & - & - \\
\hline 100 & $92.8 \%$ & $4.8 \%$ & $40 \%$ \\
\hline 200 & $96.6 \%$ & $8.6 \%$ & $72 \%$ \\
\hline 300 & $97.8 \%$ & $9.8 \%$ & $82 \%$ \\
\hline 400 & $99.1 \%$ & $11.1 \%$ & $92,5 \%$ \\
\hline 500 & $99.5 \%$ & $11.5 \%$ & $96 \%$ \\
\hline
\end{tabular}

\subsubsection{Prospects}

As an extension to the presently analyzed simulation model, it could be interesting not only to vary the consulting fee as a constant parameter but also to vary some other parameters as the Duration of the consulting session (D) time and / or the Contracting rate $(\mathrm{P})$.

As for the consulting session, it might be interesting to introduce a time factor that is coupled to the amount of money paid (e.g., the more money the customer spends, the more time he receives for the consultancy).

With regard to the contracting rate, it might be interesting to introduce a factor that boosts or reduces the Contracting rate depending on the consulting fee. This effect is supported by the assumption that the more money a prospect spends with the consulting bank, the more likely it is that he stays with it to be credited the consulting fee he paid in advance.

Moreover, the model may also be extended to further specialized areas of consulting services where the introduction of consulting fees is likely to be considered. 


\subsection{Possible Approaches to introduce a Mortgage Loan Consulting Fee in German Re- tail banks}

Based on the results of Chapter 2 and the results of the model in Chapter 3 obtained from the Monte Carlo simulation, it is obvious that the introduction of consulting fees is indeed promising in that it contributes to maximizing the estimated revenue for a bank in the field of mortgage loans.

And yet, since willingness of prospects to pay for related consulting services is rather limited as evidenced by the results of the study, see Chapter 2, several issues will have to be addressed for a successful realization of paid services in the field discussed.

Thus, the author suggests two alternative approaches.

Firstly, a quantitative approach is proposed, the basic principle of which has already been explained in chapter 1.4.1 with reference to asset management. In literature (Severidt, 2001), a cost-covering approach is suggested, but German customers most probably won't pay around $70 €$ per hour of consulting. But, as the survey of Chapter two also shows, amounts between $100 €$ and $200 €$ for four to five hours of consulting would be accepted, which relates to an hourly rate of around $25 €$. In the light of Table IV, this clearly is not cost-covering for the bank, but it would be a first step in the "right" direction. As already discussed with reference to Figure 30, however, the mere introduction of a consulting fee has the strongest impact on estimated revenue.

Secondly, the quantitative approach could be extended by elements of a volumerelated approach such as modifying the consulting fee based on the amount borrowed.

The following combinations could be imaginable:

On the basis of the amount borrowed, the customer pays a pre-determined fee of, for example $0.1 \%$ of an exemplary amount borrowed of $250,000 €$ which results in an 
absolute value of $250 €$ for the consulting fee earned by the advisor. If the customer contracts with the bank, he gets his money back.

The main advantage for the customer is the time-flatrate nature of such approach, i.e. the customer pays a predetermined amount of money, no matter how long the consulting session takes.

On the other hand, disadvantageously for the bank, with small volumes (e.g., $50,000 €$ ) the consulting fee is very small (with $0.1 \%=50 €$ ), although the given advice may be really time consuming. Another disadvantage may be that the customer fraudulently pretends a small volume to save money and contracts with another bank after having received the advice. Such "strategies", however, could be undermined by defining a fixed minimum consulting fee that is high enough to discourage fraudulent actions.

The above explained volume-related approach could be extended by introducing a time and / or complexity component. On the basis of actual time consumption for the given advice and the intended amount borrowed, the consulting fee as determined by the approach explained above is modified, which enables to appropriately account for consulting processes of increased complexity. This approach is demonstrated by the following examples:

TABLE X

COMPLEXITY AND TIME RELATED APPROACH

\begin{tabular}{|l|l|l|l|}
\hline $\begin{array}{l}\text { Amount borrowed } \\
\text { (Volume; up to) }\end{array}$ & $\begin{array}{l}\text { Estimated Time for } \\
\text { Consultancy in Hours }\end{array}$ & Hourly Rate & $\begin{array}{l}\text { Estimated Consulting } \\
\text { Fee for the Advisor }\end{array}$ \\
\hline $50,000 €$ & $1-2$ & $50 €$ & $50 €-100 €$ \\
\hline $100,000 €$ & $1-2$ & $60 €$ & $60 €-120 €$ \\
\hline
\end{tabular}

${ }^{29}$ Assumption: Complexity increases by increased amount borrowed 


\begin{tabular}{|l|l|l|l|}
\hline $200,000 €$ & $2-3$ & $70 €$ & $140 €-210 €$ \\
\hline $500,000 €$ & $3-6$ & $80 €$ & $240 €-480 €$ \\
\hline
\end{tabular}

The main advantage of the approach illustrated by Table $\mathrm{X}$ is a fair determination of the consulting fee, since it accounts for the amount borrowed, the complexity and the duration of the consulting session. Thus, it is no time-flat rate for the customer.

As with any other time dependent approach, the customer might stick to his watch in trying to save consulting fees. Possibly, there will be no trustful atmosphere and there may be some losses in communication.

The above discussed approaches may serve as a basis for banks to introduce consulting fees in mortgage loan banking and may be extended according to the respective business concept. 


\section{CONCLUSION AND FUTURE RESEARCH}

\section{Conclusion}

In Germany, it is a very emotional controversy whether to introduce consulting fees as an alternative to the standard approach or in addition to traditional commission banking. Sometimes it even seems doubtful on which side to find the better advisors: commission bankers or consulting fee bankers (Horn, 2010).

In future, a big task will be not only to define correct and adequate pricing systems for consulting fees, but it will also be necessary to define a new occupational image for the bank advisor based on consulting fees. Typical providers of other highly personal services such as tax advisors or jurists may serve as an adequate example.

More important than defining the new occupational image, however, is the creation of a sound pricing model for consulting fees in mortgage loan banking taking into consideration the findings of the present thesis.

Generally, it has been shown that the introduction of consulting fees is promising in that it contributes to maximizing the estimated revenue for a bank in the field of mortgage loans.

A key insight of the thesis reveals that the decisive factor is the very introduction of consulting fees, whereas their absolute value is of secondary concern. 


\section{Future Research}

For future research in context of the Monte Carlo Simulation model it might be interesting to apply a specific stress-testing approach called sensitivity analysis.

Sensitivity analysis is used to determine how "sensitive" a model is to changes in the value of one or multiple of the parameters and to changes in the structure of the model. By showing how the model behavior responds to changes in parameter values, sensitivity analysis is a useful tool in model building as well as in model evaluation. Thus, sensitivity analysis helps to build confidence in the model by studying the uncertainties that are often associated with parameters in models.

Furthermore, sensitivity analysis allows determining what level of accuracy is necessary for a parameter to make the model sufficiently useful and valid. If the tests reveal that the model is insensitive, then it may be possible to use an estimate rather than a value with greater precision. Sensitivity analysis can also indicate which parameter values are reasonable to use in the model. If the model behaves as expected from real world observations, it gives some indication that the parameter values reflect, at least in part, the "real world" (see Breierova et al. 1996).

In the context of this thesis it might be interesting to apply sensitivity analysis at least to the following parameters of Equation 1.

Firstly, the number of consulting sessions, for this parameter might undergo certain decline because there might be far less consulting session than assumed in chapter 3 if customers had to pay for the consulting service. And secondly the margin, which is due to the current instability of the financial markets that might result in dramatically rising margins during the next months. 


\section{REFERENCES}

[1] Bankmagazin. 2010. Wie sieht die Bank 2015 aus? Springer Fachmedien Wiesbaden $\mathrm{GmbH}$ in bankmagazin.de

[2] Bernet, B. 1996. Bankbetriebliche Preispolitik, Stuttgart 1996

[3] Bastian, Nicole. 2009. COMDIRECT UND CORTAL CONSORS. Direktbanken testen Honorarberatung. Handelsblatt

[4] Baulig, Bianca. 2010. Kommt bald die Honorarberatung? Springer Fachmedien Wiesbaden $\mathrm{GmbH}$ in bankmagazin.de

[5] Boeckhoff, Michael. 2003. Handbuch der individuellen Finanzplanung und Finanzberatung. Heidelberg

[6] Breierova, Lucia; Mark Choudhari, 1996. An Introduction to Sensitivity Analysis

[7] Deutscher Sparkassen- und Giroverband e.V. 2009. Freie Vermögensberater schlägt nun ihre Stunde? Sparkasse Nr. 11. Seite 42

[8] Eberstadt, G. 1993. Die Preispolitik im Wertpapiergeschäft der Banken, in: Gebauer, w./ Rudolph, B. (Hrsg.): Marketing für Finanzprodukte und Finanzmärkte, Frankfurt a.M..

[9] Fritzsche, Fabian. 2007. Honorarberatung im Financial Planning : Praktische Anwendung, Probleme und Lösungsansätze. Saarbrücken: VDM Verlag Dr. Mueller

[10] Fischer, Desiree. 2009. Honorarberatung aus der Sicht des vermögenden Privatkunden

[11] Hepp, Christina. 2008. Fehler- und Fehlerfolgekosten in Banken. Gabler Edition Wissenschaft. Gabler

[12] Hillig, Thomas. 2006. Verfahrensvarianten der Conjoint-Analyse zur Prognose von Kaufentscheidungen. Gabler Edition Wissenschaft. Dt. Universitäts Verlag

[13] Horn, Brigitte. 2009. Das Sowohl-als-auch-Prinzip: Honorarberatung und Provision. AssCompact Nr. 11 vom 03.11.2009. Seite 118. Bbg Betriebsberatungs GmbH 
[14] Horst, Klaus W. Schwolow, Klaus. 2009. GründerZeiten. Informationen zur Existenzgründung und -sicherung. Nr. 25. Thema Kostenrechnung. Ausgabe September 2009. Bundesminsisterium für Wirtschaft und Technologie

[15] Kersting, Hubert. Schwolow, Renate. 2009 GründerZeiten. Informationen zur Existenzgründung und -sicherung. Nr. 28. Thema Preisgestaltung. Ausgabe Juni 2009 Bundesminsisterium für Wirtschaft und Technologie

[16] LaCour-Little, Michael. The Pricing of Mortgages by Brokers. An Agency Problem?. Journal of Real Estate Research. Volume 31. No.2 2009

[17] Meyer, Bastian. 2006. Chancen und Risiken der Honorarberatung im Retailbanking. 2006. Diplomica Verlag GmbH

[18] No Name (1) 2009. Studie zur Honorarberatung - ebs-/pfi-Umfrage Finanzdienstleister signalisieren grundsätzliche Aufgeschlossenheit. Vermögen und Steuern 12 vom 01.12.2009. Seite 28. www.ebs.edu/pfi. Verlag Helmut Richardi GmbH

[19] No Name (2) 2009. Umfrage bei Entscheidern im Bankbereich - Hauptsorge: Kreditrisiken und Vertrauensverlust belasten die Geschäftsentwicklung. Vermögen und Steuern 12 vom 01.12.2009. Seite 7. www.steria-mummert.de. Verlag Helmut Richardi $\mathrm{GmbH}$

[20] No Name (3) 2009. Gastkommentar: Wer schützt die Verbraucherschützer? Portfolio international vom 10.11.2009. portfolio Verlagsgesellschaft mbH

[21] No Name (4) 2009. Honorarberatung Comdirect. Portfolio international vom 10.11.2009. portfolio Verlagsgesellschaft $\mathrm{mbH}$

[22] Powley, Tanja. 2008. Mortgage proc fees on way out. Money Marketing. July 17 th 2008

[23] Robinson, John H.. 2007. Who's the Fairest of Them All? A Comparative Analysis of Financial Advisor Compensation Models. Journal of Financial Planning.

[24] Schwefel, Hans-Paul. 1995. Evolution and optimum seeking. A WileyInterscience Publication. JOHN WILEY AND SONS, INC.

[25] Severidt, Katrin. 2001. Beratungshonorare in Banken: Wettbewerbsbedingungen und Kundenpraeferenzen. Wiesbaden. Dt. Univ.-Verl.

[26] Skiera, B. Spann, M. 1998. Gewinnmaximale zeitliche Preisdifferenzierung für Dienstleistungen. Zeitschrift für Betriebswirtschaft, 68, 703-718.

[27] Schmidt, Karl Matthäus. 2009. Honorar für die Bankberatung - Durchbruch für ein neues Geschäftsmodell? Zeitschrift für das gesamte Kreditwesen Nr. 1. 
[28] Spann, Martin. 2008. Preismanagement. Universität Passau. Lehrstuhl für Marketing und Innovation. Vorlesung Sommersemester 2008

[29] Walter, Herbert. 2009. B A N K B E R A T U N G. Mehr Ehrlichkeit, weniger Rendite. DIE ZEIT, 46 - 05. November 2009. http://www.zeit.de/2009/46/ForumBankenvertrauen Internet Access: 2009-11-19

[30] Wuebker, Georg. Aldershot et al. 2008. Price management in financial services ; smart strategies for growth.

[31] Wuebker, Georg. Niemeyer, Frank. 2008. Erfolgsfaktoren der Honorarberatung. die bank

[32] Wuebker, Georg. Niemeyer, Frank. Krauss, Jochen. 2009. Professionelles Preismanagement für Sparkassen. Deutscher Sparkassenverlag Stuttgart

[33] Wuebker, Georg. Engelke, Jan. Gutsche, Jörg. 2009. Financial Services. Ertragspotentiale nutzen. Innovatives Pricing von Konsumentenkrediten.

[34] Wuebker, Georg. Simon - Kucher \& Partners. 2006. Power Pricing für Banken. Wege aus der Ertragskrise. Campus Verlag Frankfurt/New York

[35] Michel, S. Zellweger, C. 2007. Pricing bei Dienstleistungen und Yield Management. Grundlagen, Beispiele und Herausforderungen. Schäfer-Matzak, A./Jüttner, $\mathrm{U}$.

[36] ZEIT ONLINE. 2009. B A N K B E R A T U N G. Der Preis der Unabhängigkeit.http://www.zeit.de/wirtschaft/2009-11/comdirect-beratung.

Access date: $2009-11-19$ 


\section{APPENDICES}

APPENDIX I: AVARICE IS WICKED

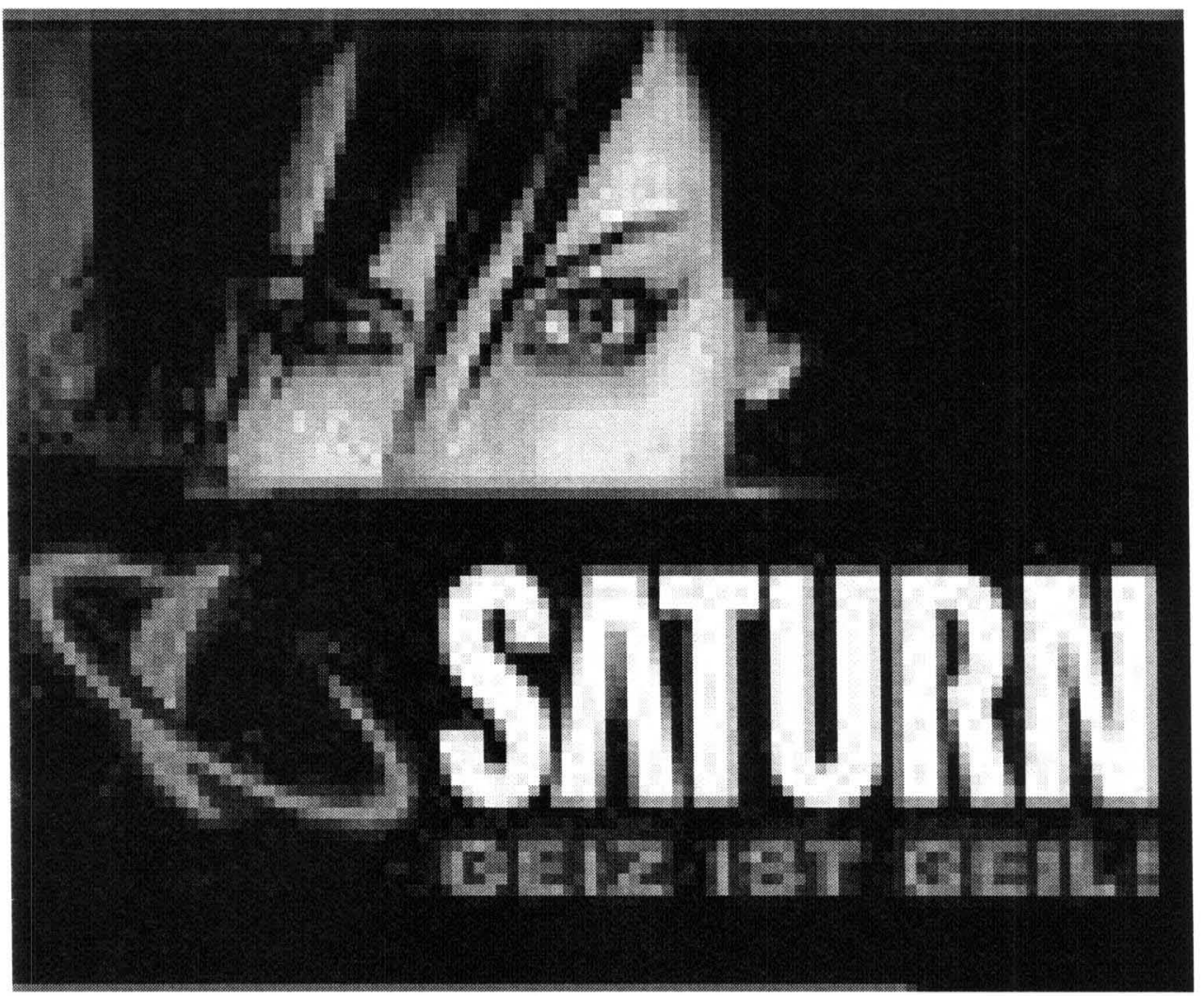

SOURCE: INTERNET 


\section{APPENDIX II: DOMINATING PRICE FACTOR IN BANKING}

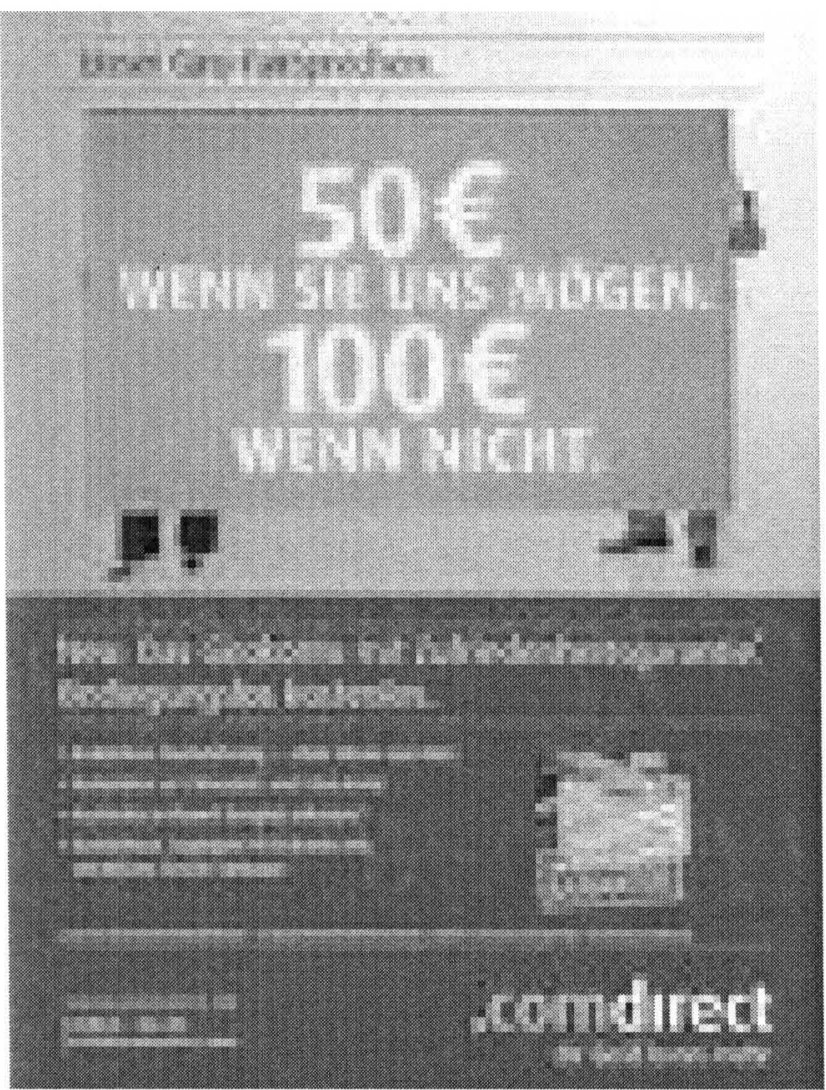

50 Euro if you like us, 100 if you don't.

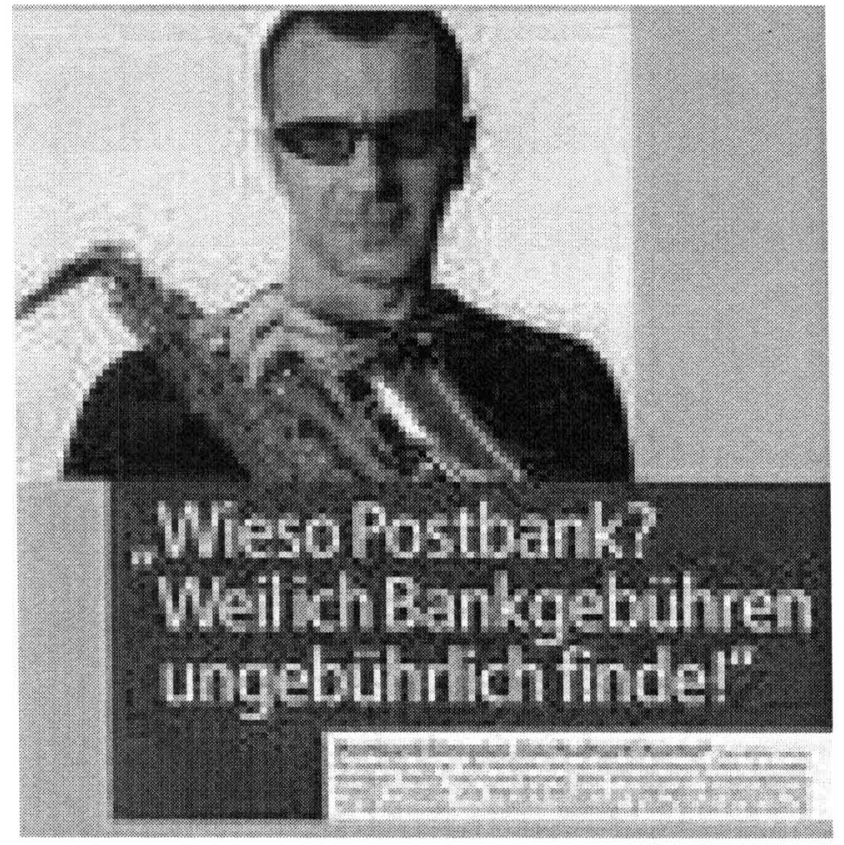

Why Postbank? Because I think dues are undue!

SOURCE: INTERNET 
APPENDIX III: CREDIT RATING RELATED MORTGAGE LOAN PRICES

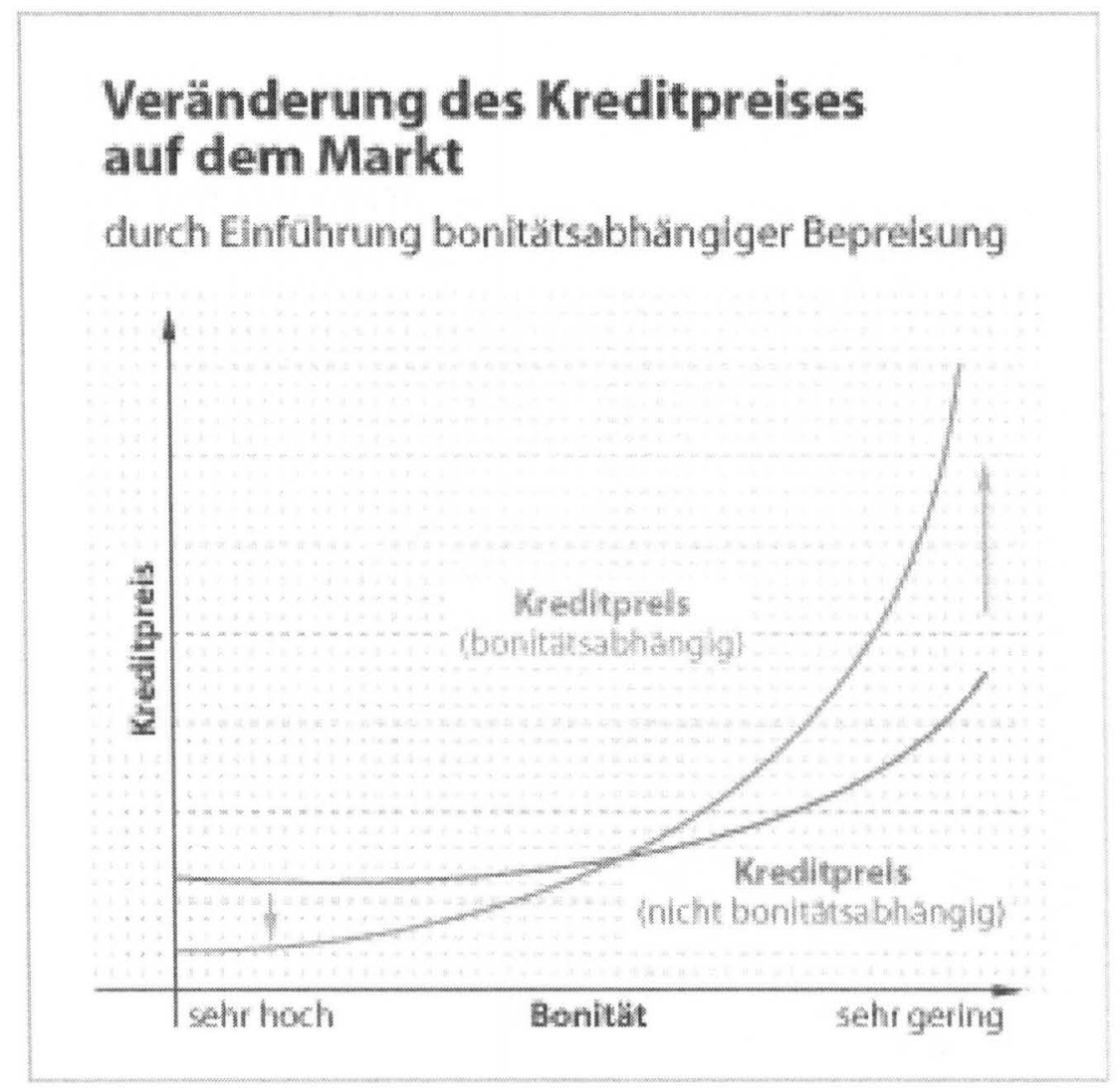

Source on the basis of: http://www.banklounge.de dated 2010-03-17 


\section{APPENDIX IV: QUESTIONNAIRE}

1) Zu welcher Institutsgruppe gehört die Bank, bei welcher Sie Ihre Baufinanzierung abgeschlossen haben / wo planen Sie, Ihre Baufinanzierung abzuschließen?

Which category of financial institution does the bank belong to where you concluded your mortgage loan agreement / which category of financial institution do you plan to choose for contracting your mortgage loan?

\begin{tabular}{|l|l|}
\hline$\square$ Sparkassen / Volksbanken & $\square$ Savings bank / credit union \\
\hline$\square$ Großbanken (DB, DreBa etc.) & $\square$ Private banks (DB, DreBa) \\
\hline$\square$ Versicherungen & $\square$ Insurances \\
\hline$\square$ Bausparkassen & $\square$ Thrift institution \\
\hline$\square$ Direktbanken & $\square$ Direct bank \\
\hline$\square$ Andere & $\square$ Others \\
\hline
\end{tabular}

II) Warum haben Sie / planen Sie, gerade bei dieser Bank Ihre Baufinanzierung abzuschließen?

Why exactly did you choose / do you plan to choose that bank for contracting your mortgage loan?

\begin{tabular}{|l|c|}
\hline$\square$ Service & $\square$ Overall Service \\
\hline$\square$ Beratungsqualität & $\square$ Quality of advice \\
\hline$\square$ Abwicklungsdauer & $\square$ Processing time \\
\hline$\square$ Betreuer & $\square$ Advisor \\
\hline$\square$ Zinssatz & $\square$ Interest rate \\
\hline$\square$ Hausbank & $\square$ Main bank \\
\hline$\square$ Andere & $\square$ Other \\
\hline
\end{tabular}

(Mehrfachnennungen möglich)

(Check all that apply)

III) Wie lange sind Sie bei Ihrer Hausbank bereits Kunde?

For how long have you been a customer with your bank?

\begin{tabular}{|l|l|}
\hline$\square<1$ Jahr & $\square<1$ year \\
\hline$\square$ 1<x<5 Jahre & $\square 1<x<5$ years \\
\hline$\square 5<x<10$ Jahre & $\square 5<x<10$ years \\
\hline$\square>10$ Jahre & $\square>10$ years \\
\hline$\square$ Ich habe keine Hausbank & $\square$ I have none \\
\hline
\end{tabular}


IV) Bislang ist die Beratungsleistung für Baufinanzierungen bei nahezu allen deutschen Banken kostenlos. Können Sie sich vorstellen, für diesen Service zukünftig Geld zu bezahlen, wenn dadurch

Up to now advice for mortgage loans is free with almost all German banks. Could you imagine paying money for that service in the future if so, for what reason?

\begin{tabular}{|c|c|}
\hline$\square$ Der Effektivzins für den Kredit sinkt & $\begin{array}{c}\square \text { The price for the mortgage loan would } \\
\text { drop }\end{array}$ \\
\hline$\square$ Die Beratungsqualität steigt & $\square$ The quality of advice would rise \\
\hline$\square$ Die Beratung umfänglicher ist & $\begin{array}{c}\square \text { The quality of advice would be more } \\
\text { extensive }\end{array}$ \\
\hline $\begin{array}{l}\square \text { Die Beratung produktneutraler und } \\
\text { objektiver wird (weniger provisionsorientiert) }\end{array}$ & $\begin{array}{c}\square \text { The advice would be more (product- } \\
\text { Ineut objective (less provision oriented) }\end{array}$ \\
$\begin{array}{l}\square \text { Die Beratungsleistung nur dann in } \\
\text { Rechnung gestellt wird, sofern Sie die } \\
\text { Baufinanzierung bei einem anderen Institut } \\
\text { abschließen }\end{array}$ & $\begin{array}{l}\square \text { The ild choose to contract with another finan- } \\
\text { cial institution }\end{array}$ \\
\hline
\end{tabular}

(Mehrfachnennungen möglich)

(Check all that apply)

V) Wie viel Geld sind Sie bereit für eine gute, objektive Baufinanzierungsberatung auszugeben?

How much money are you willing to pay for a good, extensive advice for mortgage loans?

\begin{tabular}{|l|l|}
\hline$\square<100$ & $\square<100$ \\
\hline$\square>100$ aber weniger als 200 & $\square>100$ but less than 200 \\
\hline$\square>200$ aber weniger als 500 & $\square>200$ but less than 500 \\
\hline$\square>500$ & $\square>500$ \\
\hline$\square$ Abhängig vom Darlehensvolumen bis & $\square$ Depending on the amount borrowed \\
zu 0,1\% mit Sockelbetrag & up to $0.1 \%$ \\
\hline
\end{tabular}

(Mehrfachnennungen möglich) (Check all that apply)

VI) Würden Sie eher bei einer Bank Ihre Baufinanzierung abschließen, die die Beratungsleistung für Geld anbietet?

Would you rather prefer contracting with a bank that takes money for mortgage loan advising?

\begin{tabular}{|l|l|}
\hline$\square$ Ja & $\square$ Yes \\
\hline$\square$ Nein & $\square$ No \\
\hline$\square$ Spielt keine Rolle & $\square$ Doesn't matter \\
\hline
\end{tabular}


VII) Stellen Sie sich vor, Sie könnten zwischen zwei Modellen entscheiden, einer individuellen kostenpflichtigen Baufinanzierungsberatung und einem kostenfreien Standardprogramm. Welches würden Sie wählen?

Please imagine you could choose between two types, an individual mortgage loan advice with costs and a standardized model exempt from any charges. Which one would you choose?

\begin{tabular}{|c|l|}
\hline \begin{tabular}{|l|} 
rung \\
Kostenpflichtige Individualbaufinanzie-
\end{tabular} & $\square$ Individual mortgage loan advice with \\
\hline$\square$ Kostenloses Standardmodell & $\begin{array}{l}\square \text { Standardized model exempt from } \\
\text { charges }\end{array}$ \\
\hline
\end{tabular}

VIII) Bei wie vielen Banken sind Sie derzeit Kunde?

How many different bank connections do you currently have?

\begin{tabular}{|l|}
\hline$\square 1$ \\
\hline$\square 2-3$ \\
\hline$\square>3$ \\
\hline
\end{tabular}

IX) Was sind die Gründe für eine Mehrbankenverbindung?

What are the reasons for these different bank connections?

\begin{tabular}{|l|l|}
\hline$\square$ Preis & $\square$ Price \\
\hline$\square$ Beratungsqualität & $\square$ Quality of Advice \\
\hline$\square$ Kompetenz & $\square$ Competence \\
\hline$\square$ Produktvielfalt & $\square$ Variety of Products \\
\hline$\square$ Kundennähe (Filialnetz) & $\square$ Proximity to customer \\
\hline$\square$ Image des Instituts & $\square$ Image \\
\hline$\square$ Andere & $\square$ Other \\
\hline
\end{tabular}

(Mehrfachnennungen möglich)

(Check all that apply)

X) Wie alt sind Sie?

How old are you?

\begin{tabular}{|l|l|}
\hline$\square<20$ Jahre & $\square<20$ years \\
\hline$\square 20<x<30$ Jahre & $\square 20<x<30$ years \\
\hline$\square 30<x<50$ Jahre & $\square 30<x<50$ years \\
\hline$\square>50$ Jahre & $\square>50$ years \\
\hline
\end{tabular}


XI) Wie ist Ihr Familienstand?

What is your marital status?

\begin{tabular}{|l|l|}
\hline$\square$ Ledig & $\square$ Unmarried \\
\hline$\square$ Verheiratet & $\square$ Married \\
\hline
\end{tabular}

XII) Welcher Berufsgruppe gehören Sie an?

Which occupation group do you belong to?

\begin{tabular}{|l|l|}
\hline$\square$ Angestellter & $\square$ Employee \\
\hline$\square$ Selbständiger & $\square$ Free-lancer \\
\hline$\square$ Schüler / Student & $\square$ Scholar/student \\
\hline$\square$ Rentner & $\square$ Retired \\
\hline
\end{tabular}




\section{APPENDIX V: NOMENCLATURE}

\begin{tabular}{|c|c|}
\hline $\mathrm{AB}=$ & Amount Borrowed \\
\hline $\mathrm{Cf} .=$ & Confer \\
\hline $\mathrm{D}=$ & Duration of consulting Sessions \\
\hline e.g. $=$ & For Example \\
\hline $\mathrm{ER}=$ & Estimated Revenue \\
\hline $\mathrm{F}=$ & Fixed consulting fee \\
\hline $\mathrm{FC}=$ & Fixed costs \\
\hline i.e. $=$ & Id est $=$ that is \\
\hline $\operatorname{IRBA}=$ & Internal Rating Based Approach \\
\hline $\mathrm{M}=$ & Margin \\
\hline $\mathrm{MC}=$ & Monte Carlo (Simulation) \\
\hline$N=$ & Number of consulting sessions \\
\hline$P=$ & Contracting Rate \\
\hline $\mathrm{R}=$ & Hourly rate for consulting session \\
\hline $\mathrm{POD}=$ & Probability Of Default \\
\hline
\end{tabular}




\section{CURRICULUM VITAE}

Name

Alexandra Antonia Behrens

Address

Balzhalde 16

71665 Vaihingen Enz

Germany

DOB

August $23^{\text {rd }}, 1979$

Education

$2002-2006$

2001- 2002

$1999-2001$
Hamburger Fern-Hochschule, Hamburg Dipl-Wirtsch.-Ing. (FH) Grade: 1.7 (B) Chamber of Commerce, Nordschwarzwald Training supervisor for business administration Chamber of Commerce, Stuttgart Diploma in banking and finance; Grade: 1.4 (A)

Professional Experience

August 2005 until today

August 2004 - July 2005

June 2003 - July 2004

June 2001 - May 2003

Credit Risk Department (BW-Bank Stuttgart) Credit Risk Department (BW-Bank AG Stuttgart) Management Assistance (BW-Bank AG Pforzheim) Trainee program with a focus on analysis of companies and customer relationship management

Awards

Chamber of Commerce IHK Nordschwarzwald, Stipend 